\title{
Arbor
}

\section{Riesgo y desgracia de las ciudades históricas}

\section{Fernando Chueca Goitia}

Arbor CLXX, 671-672 (Noviembre-Diciembre 2001), 501-542 pp.

En este largo artículo, que mas que un artículo parece un tratado, el autor discurre sobre la condición histórica de la ciudad. Cómo la ciudad se forma y es consecuencia de la historia; sobre su carácter testimonial que la convierte en verdadero archivo de la historia.

Luego discurre el escritor sobre los muchos factores que amenazan a las ciudades históricas y que en gran medida son consecuencia de la mentalidad del hombre masa indiferente a todo aquello que contravenga a sus apetitos y a su deseo de enriquecimiento, atropellando otros valores culturales.

Se analizan las actitudes del político y del técnico frente al intelectual, cada vez menos influyente y más privado de armas y recursos.

Se trata igualmente del contagio de las grandes metrópolis, no sólo sobre el medio rural sino sobre la pequeña ciudad provinciana que tantas veces ha recogido no sólo el depósito de la historia sino la suma de las más delicadas bellezas de la aquitectura y el urbanismo tradicionales.

Sobre la arquitectura típica regional el autor destaca su realidad como legitima hijos de la raza y de la naturaleza circundante, cuyos valores se van perdiendo por una falsa vanidad, por un equivocado progresismo y sobre todo por una evidente incultura de la sociedad.

Para no caer en un profundo pesimismo ante tantos enemigos como los que amenazan a las ciudades históricas y a los pueblos tradicionales, nos dice el autor, que, en último término, todos los remedios que podamos proponer se reducen a un problema de cultura, de ilustración; en suma de educación de las masas, educación de las clases dirigentes, educación de los técnicos. 


\section{La ciudad como Historia}

Empezaremos por hacer un Elogio de las viejas ciudades que llamamos históricas y que pueblan el viejo y parte del nuevo mundo.

En primer lugar la ciudad no sólo es historia sino que es un verdadero archivo de la historia. En ella se condensa el proceso histórico y por eso alterarla, desconocerla y transformarla torpemente entrañaría una gran responsabilidad, pues no sólo alteraremos una obra de arte sino un documento histórico del máximo valor.

Tomemos un ejemplo: la ciudad medieval se nos aparece a todos como una ciudad amurallada. Esto podrá parecer un hecho físico accidental, pero la realidad profunda es que se trata de un hecho condicionante del más largo alcance. En la Edad Media aparece la ciudad como una organización comunal. Precisamente una de tantas causas que influyeron en el nacimiento de las comunidades fue la necesidad de organizar un sistema de contribuciones voluntarias para atender a las obras apremiantes de construcción y conservación de las murallas. Max Weber ha estudiado la repercusión de las murallas o, en un sentido más amplio, de la ciudad entendida como fortaleza y guarnición, en la regulación administrativa de la propiedad inmobiliaria netamente burguesa. La condición jurídica de la casa y de la tierra que poseían los burgueses estaba determinada por la obligación de vigilar y defender la fortaleza. La ciudad no sólo defendía a sus propios habitantes, sino que generalmente era lugar de refugio para gentes y ganados del campo circunvecino. Por eso era frecuente que las cercas tuvieran mucha mayor extensión que la necesaria para encerrar la superficie edificada. Estas zonas vacías solían servir para albergar en ellas los ganados y otros pertrechos cuando la guerra asolaba la comarca o la inseguridad lo aconsejaba. En cambio, numerosos señores y concejos prohibieron repetidamente que las propiedades inmuebles del interior de la cerca pasasen a manos de iglesias, órdenes monásticas o gentes exentas de tributación, para no disminuir los ingresos concejiles ni los derechos reales. Disposiciones en este sentido se encuentran en multitud de fueros españoles. En una palabra: como decía Max Weber, la propiedad inmobiliaria burguesa tenía una especial, regulación, que es lo que caracteriza a la comuna medieval.

Enrique IV de Castilla concedió el año 1465 unas determinadas franquicias a los moradores de Madrid, bien fueran moros, cristianos o judíos, pero obligándoles a no salir de sus muros, «non salgan a bevir ni morar fuera de los arrabales», y a que si lo hicieren, pecharan cada uno con dos mil maravedises para el repaso de los muros y 
cerca de la dicha villa. Los madrileños tenían obligación de velar y guardar el Alcázar, y como parece ser que muchos se zafaban de hacerlo, los pocos que lo cumplían se quejaron al rey en 1473, diciendo que la carga era muy fatigosa y que si seguían así las cosas la villa se despoblaría.

La necesidad de estas murallas, que caracterizaban a la ciudad medieval, fue en muchos casos el origen de las finanzas municipales. Lo que comenzó por ser una contribución voluntaria, adquirió pronto carácter obligatorio, extendiéndose no sólo a la fortificación sino a otras obras comunes, como el mantenimiento de las vías públicas. Aquel que no se sometía a esta contribución era expulsado de la ciudad y perdía sus derechos. La ciudad por consiguiente, acabó por adquirir una personalidad legal que estaba por encima de sus miembros. Era una comuna con personalidad jurídica propia e independiente. Esta personalidad jurídica otorga a la ciudad un clima de franquicia y de privilegio, de libertad, en medio del mundo rural circundante, mucho más sometido. Dice un proverbio alemán que el aire de las ciudades es libre y hace libres a los hombres: Die Stadtluft macht frei. Desde entonces, siempre ha conservado la ciudad ese clima libre e independiente que es uno de los alicientes que han atraído al hombre hacia ellas. Hoy no es porque exista un estatuto jurídico diferente para el burgués y el campesino, sino por otras causas que tienen que ver con la variedad, los recursos, las posibilidades. Si en la ciudad de hoy no existe una diferencia de status jurídico, sí existe de status social.

Estas y otras circunstancias, sobre todo de origen económico, dieron lugar a que Henri Pirenne definiera la ciudad medieval como «una comuna comercial e industrial que habitaba dentro de un recinto fortificado, gozando de una ley, una administración y una jurisprudencia excepcionales que hacían de ella una personalidad colectiva privilegiada».

Hoy en día no quedan murallas, y esto parece ya historia pasada; pero la realidad es otra, pues la existencia de aquellas pretéritas defensas gravita sobre las ciudades de hoy no sólo por lo que respecta a una estructura física todavía vigente, sino por el papel que jugaron en la constitución de la comunidad municipal, que en grandes rasgos ha prevalecido y prevalece en nuestros días. La ciudad, como la realidad histórica, no es nunca independiente de las etapas por las que pasó en su evolución: es actualización de ellas y su proyección hacia el porvenir.

Sin embargo, en la misma Edad Media, las ciudades que gozaban de un estamento especial para los burgueses eran una minoría, reducida casi exclusivamente al Occidente cristiano. Es decir, el Ayuntamiento urbano, tal y como lo conocemos, era desconocido en Asia, en el Próximo 
Oriente y en el mundo islámico. Muchas ciudades orientales eran una fortaleza y tenían mercado como las occidentales, pero carecían de un estatuto jurídico propio. Son, pues, categorías de ciudad completamente diferentes que no pueden abrazarse en una definición común.

Pasemos de la Edad Media al llamado mundo moderno, en el que los mejores espíritus trataron de fundar su especulación en el criterio de evidencia. Esta evidencia no la tiene el hombre por medio de los sentidos, sino por medio de su razón. Todo lo que no es racional viene a ser sospechoso. Las ciudades antiguas, como producto de la historia, no podían ponerse como ejemplo de construcciones racionales. Los hombres de entonces no vieron en ellas más que desconcierto y caos. Esta es la postura de Descartes:

«Así aquellas antiguas ciudades que al principio sólo fueron villorrios y se convirtieron, por la sucesión de los tiempos, en grandes ciudades, están por lo común tan mal compuestas, que al ver sus calles curvas y desiguales se diría que la casualidad, más que la voluntad de los hombres usando de su razón, es la que las ha dispuesto de esta manera».

Todavía en el siglo XVII la historia no tiene que ver nada con la razón, incluso se opone a ella; lo que la razón hace — por ejemplo, una ciudad constituida con arreglo a un plan unitario-, es lo contrario de lo que la historia va acumulando en su curso y que parece obra del azar.

Trataron, pues, los hombres de los siglos XVII y XVIII de racionalizar la ciudad, de pensarla more geométrico, por considerar que todo lo anterior no era sino obra del azar. Negando, pues, la razón histórica, le daban la razón a la historia, añadiendo un nuevo ingrediente al ser histórico de la ciudad. La historia de la ciudad se enriquecía con un nuevo capítulo, y cada una de aquellas ciudades - claro está, no lo fueron todas - que quectó afectada por el impacto del racionalismo, siguió viviendo su propia vida histórica, matizada de una u otra manera según las complejas circunstancias en que se produjo el hecho y según el alcance del mismo.

El racionalismo dio nacimiento a la ciudad como obra de arte, como arti-facto. Con anterioridad, las ciudades habían sido bellas por su crecimiento natural y orgánico, como es bello un árbol. Nada en su desenvolvimiento había sido ordenado por la voluntad de los hombres usando de su razón, pero eran hijas de la voluntad histórica usando de la razón vital. Ahora bien: ¿hubiera, en cambio, dejado la ciudad de ser hija de la historia si no hubiera recogido en su evolución las más importantes concepciones del mundo, lo que los alemanes llaman Weltanschauung? Al fin y al cabo, el que la historia se haga en la ciudad obliga a que la ciudad se haga en la historia. 


\section{Riesgo y desgracia de las ciudades históricas}

Las primeras huellas del racionalismo en el cuerpo físico de la ciudad fueron tímidas, y a veces un poco toscas. En relación con los edificios importantes, se construyeron plazas pensadas con simetría y adecuación artísticas; otras veces, estas plazas regulares constituían por sí solas entidades completas, como sucedió con nuestras típicas plazas mayores del tiempo de los Austrias. Cuando las circunstancias lo permitían, se trazaban ciudades de plano regular, como las de nuestra colonización americana. Entonces el sistema seguido fue el de la cuadrícula, muy geométrico y muy cartesiano, pero falto en general de sutileza artística. La cuadrícula había sido utilizada por los griegos también cuando el racionalismo, o si se quiere el idealismo, presidía el pensamiento. Lo fue también por los romanos, llevados de su sentido práctico.

Con la llegada del mundo barroco la ciudad sufrió una mayor y trascendental transformación. Para ello, sobre la base inicial del racionalismo cartesiano, que había sentado ya la necesidad de la ciudad, como arti-facto, como faena de la voluntad humana iluminada por la razón, tuvieron que producirse dos hechos, uno de carácter estético y otro de carácter político-económico. El primero fue el desarrollo de la perspectiva, del perspectivismo, como concepción del espacio artístico, y el segundo, el auge del poder absoluto del príncipe unido a la economía consumidora de la corte.

Ambas características se dan de una manera extremada en las llamadas Residenzstädte o ciudades principescas. Si no hubiera existido el poder onmímodo y convergente del príncipe, si no hubiera existido una corte consumidora capaz de hacer prosperar el lujo, el nuevo estilo perspectivista, que no está fundado en ninguna necesidad funcional ni utilitaria, sino en el puro deleite, que en ocasiones llega al orgulloso placer de forzar a la naturaleza, no hubiera podido materializarse como lo hizo. Igualmente, si el arte no hubiera alcanzado con el uso de la perspectiva las cimas que alcanzó en el barroco, el poder de los príncipes y el lujo de las cortes no habrían logrado la expresión esplendorosa que tuvieron en su tiempo y que hoy prevalece como recuerdo de su grandeza.

El siglo XIX provocó en la ciudad alteraciones de un orden muy diferente que las que trajo el período barroco. La revolución industrial, basada en los postulados del utilitarismo y en la política del laissez faire, llevó al convencimiento de que lo más importante era aumentar la riqueza de los individuos y de las naciones por todos los medios posibles. Con este criterio, todos los valores humanos, sociales, estéticos, se supeditaron al despotismo de la producción y esto tuvo consecuencias materiales, no muy agradables, por cierto, en la forma y desarrollo de las ciudades. 
En efecto, la ciudad se ha ido formando y conformando paulatinamente al correr de la historia. Sucede un gran acontecimiento político y el rostro de una ciudad tomará nuevas arrugas, dijo Spengler o bien: los gestos de la ciudad representan casi la historia psíquica de la cultura. Una vez que la ciudad se ha implantado en el terreno propicio, implantación o fundación que en la antigüedad tenía un carácter litúrgico y equivalía a transformar el nuevo solar en terra patrum, patria, la naturaleza humana va trazando las líneas de la nueva estructura, en un proceso vital en el que se halla implicado un cúmulo de costumbres, tradiciones, sentimientos, actitudes, característicos de una determinada colectividad. Pero es más: estas estructuras que han ido conformándose a través de este proceso, acaban por constituir ellas mismas una segunda naturaleza; es decir, estas estructuras reobran a su vez sobre los habitantes, que se encuentran con una exterior realidad con la que ya tendrán que contar.

En una palabra, siempre que tratemos de buscar el ser último, la realidad radical de una ciudad, nos encontraremos, por un lado, con una organización física, con unas instituciones, con una serie de calles, edificios, luces, tranvías, teléfonos, tribunales, hospitales, escuelas, universidades, etc., pero también, por otro, con un conjunto de costumbres, de tradiciones y sentimientos que definen algo que muchos, entre ellos Spengler, han denominado el alma de la ciudad. No podemos decir que esa realidad radical corresponde solo a uno de estos órdenes, al físico o al moral, sino a algo que los resume y acoge conjuntamente. Puesto que los contenidos de esta organización física y moral de la ciudad se están, como hemos dicho, modelando y modificando uno a otro por su mutua interacción, este fenómeno, tiene que producirse dentro de un ámbito que no puede ser otro que el de la vida de la propia ciudad, que en este caso no es sino la historia. Lo mismo que la filosofía orteguiana ha definido al hombre como una realidad vital, trasladado este concepto al área más vasta de lo colectivo en la que se mueve la ciudad, definiríamos ésta como una realidad histórica; es decir, para nosotros, esa última instancia no es otra ni puede ser otra que la historia. La ciudad, en última y radical instancia, es un ser histórico.

A nuestro juicio, una vez sentado esto, todos los diversos, inquietantes y muchas veces contradictorios aspectos de la ciudad, imposibles a primera vista de reducir a unidad, se aclaran y conjugan en jerárquica ordenación. Pero esto exige que reanudemos la cuestión bajo un enfoque diferente.

A la ciudad, en cierto modo como a la persona humana, le acontece que siempre es la misma y nunca es lo mismo. Londres, París, Sevilla 
o Moscú habrán variado y seguirán variando considerablemente a través del tiempo, pero en ningún momento estas alteraciones han podido llevarlas a tal pérdida de su propia mismidad que una haya podido confundirse con otra, no digo ya en un período simultáneo, sino en períodos distantes de su evolución. Cuando una ciudad ha perdido su propia mismidad, cuando en un cierto estado se ha desvanecido toda referencia a su pasado, es que esta ciudad ha muerto y ha dado paso a otra diferente.

Se nos dirá, y es cierto, que las ciudades, por el hecho de su invariable emplazamiento, de su fuerte ligamen a la tierra, están en la imposibilidad de intercambiarse, de perder su individualidad, y que aunque una ciudad desapareciera por completo, arrasada hasta no quedar ni la ceniza de sus hogares, la que se construyera en el propio lugar tendría siempre que ver con ella. Pero esto no excluye nuestra tesis, ya que al decir que la ciudad, en cuanto tal, tiene personalidad y se mantiene a través de la historia, no hacemos distingos sobre la naturaleza de las causas de dicha mismidad, conviniendo en que una de ellas - aunque no la única- es, evidentemente, su emplazamiento físico, su ligamen a la tierra. Tampoco es extraño a la persona humana y a su consistencia individual su ser biológico.

El hecho de que una ciudad hunda sus raíces en la tierra madre y se implante en ella de una determinada manera, diferencia y diferenciará siempre a la ciudad de la máquina, del instrumento, e impedirá que pueda producirse en serie. A querer, puede fabricarse la casa en serie, la casa prefabricada, pero cuando muchas de estas casas tengan que implantarse en el suelo, formando un conjunto, será obligado hacerlo de una manera única, intransferible.

Posiblemente, la singular implantación de la ciudad sobre la tierra, geología y paisaje, nos descubriría indiferencias radicales con otros asentamientos de tipo industrial o técnico. Al referirnos a la ciudad hemos dicho implantación, y no por capricho, sino por considerar que este término expresa mejor que otro la relación entre naturaleza y ciudad. Implantar significa fundar, establecer, instituir, empezar a poner en práctica algo nuevo. La ciudad no se sitúa sobre el terreno sin más; se funda sobre la tierra propicia que han señalado los dioses. Cuando los romanos fundaban una ciudad, cavaban un pequeño foso, llamado mundus, y en él los jefes de las tribus que iban a constituir esta nueva ciudad iban depositando un puñado de tierra del suelo sagrado donde yacían sus mayores. Desde este momento la nueva ciudad era también terra patrum, patria.

La tierra donde la ciudad se implanta es siempre patria. Tito Livio decía de Roma: «No hay ninguna plaza en esta ciudad que no esté 
impregnada de religión y que no esté ocupada por alguna divinidad ... los dioses la habitan». En mayor o menor grado, toda ciudad participa de este carácter sagrado y es un santuario, si no de la religión, por lo menos de la historia. De esta forma, el suelo convertido en patria tiene que tener una especial significación. La ciudad se implanta en él, es decir, se arraiga como el vegetal. Una factoría, en cambio, más que implantarse lo que hace es imponerse sobre la tierra, utilizarla en su provecho, violentarla si es preciso. Es un acto de imposición en lugar de implantación, posturas a todas luces antitéticas. Si la ciudad conforma la naturaleza, la industria generalmente la deforma; es la diferencia de verla como patria o como instrumento.

Nunca he creído que una ciudad digna de este nombre sea algo total y absolutamente opuesto al campo, en abierta hostilidad al medio natural. Muchos, sin embargo, han considerado que es así y han definido la ciudad en forma negativa, como lo que no es campo, lo cual me parece erróneo, primero porque tal definición, falta de notas positivas, es notoriamente incompleta, y, segundo, porque la ciudad es, a su modo, también campo, aunque sea campo conformado, campo hecho patria. Ortega parece recaer en la postura negativista cuando dice: «La ciudad es un ensayo de secesión que hace el hombre para vivir fuera y frente al cosmos, tomando de él sólo porciones selectas y acotadas». Sin embargo, en la definición orteguiana existe una contradicción latente. El hombre pretende vivir fuera y frente al cosmos, es decir, acusa Ortega el carácter de la ciudad como opuesto al campo. Pero -he aquí la contradicción - lo que hace para conseguirlo es retirar, secesionar porciones selectas de ese cosmos en el que al final sigue viviendo. Nosotros diríamos, salvando la contradicción, que el hombre separa y conforma esas porciones para vivir, no frente al cosmos, sino en una nueva relación con él, en relación de patria.

En efecto, las ciudades han acotado significativos trozos de este planeta, pero en ellos la naturaleza, conformada y potenciada, ha seguido existiendo como basamento físico y espiritual de la obra humana. En esos espacios acotados han quedado, por ejemplo, los ríos, deidades míticas y venas vitales, y aunque hayan sido, en su curso por la ciudad, canalizados o constreñidos a otras exigencias urbanas, no por eso el Sena, el Arno o el Danubio dejan de ser lo que son. La ciudad se implanta, pues, en el cosmos, no se impone.

A estas consideraciones sobre la implantación de las ciudades en la naturaleza habíamos llegado al afirmar la individualidad de aquellas, su no desmentida mismidad a través de la historia. Es, pues, ocasión de que volvamos al punto de partida. Esta individualidad, este ser 
único de una ciudad con respecto a otras, tiene claras raíces materiales, no sólo originadas por el sitio, por el emplazamiento (aunque pueden existir semejanzas, no pueden darse dos emplazamientos idénticos), sino por la propia estructura de la ciudad que, a la larga, se va convirtiendo en otra segunda naturaleza. La ciudad misma se resiste a perecer, es una de las más imperecederas reacciones humanas. De aquí su valor singular como testimonio histórico. Los urbanistas han estudiado lo que han denominado ley de pervivencia del plano. El análisis de la evolución temporal de las ciudades ha conducido a la constatación de que si bien la edificación se transforma y se sustituye al correr de los años, el plano generalmente permanece o sufre muy contadas rectificaciones. Córdoba, Toledo o Granada conservan barrios donde el trazado musulmán se mantiene incólume. El plano de Madrid que dibujó Texeira en 1651 es, en grandes líneas, con variaciones insignificantes, el plano actual del casco de la capital. Las ciudades, como los ofidios, cambian de piel, pero su ser permanece inalterable.

Pero hay más: no sólo son raíces materiales las que aseguran la permanencia de las ciudades como entes individuales. Existen otras de índole espiritual; existe el alma de la ciudad. Esta es la tesis de Spengler a que nos referíamos en un principio.

«La ciudad - dice el sociólogo americano Robert E. Park- es algo más que un conjunto de individuos y de conveniencias sociales; más que una serie de calles, edificios, luces, tranvías, teléfonos, etc., algo más también que una mera constelación de instituciones y cuerpos administrativos: audiencias, hospitales, escuelas, policía y funcionarios civiles de toda suerte. La ciudad es más un estado de alma (a state of mind), un conjunto de costumbres y tradiciones, con los sentimientos y actitudes inherentes a las costumbres y que se transmiten por esta tradición. La ciudad, en otras palabras, no es un mecanismo físico ni una construcción artificial solamente. Está implicada en el proceso vital del pueblo que la compone; es un producto de la naturaleza y particularmente de la naturaleza humana».

Y más adelante sigue diciendo Park que la ciudad radica en las costumbres y en los hábitos de sus habitantes, que posee tanto una organización física como moral, que se modelan y modifican una a otra por su mutua interacción. La estructura de la ciudad, que, primeramente, impresiona por su complejidad tiene por base la naturaleza humana, de la cual es expresión. Pero a su vez esta estructura, ya formada, reobra sobre sus habitantes, que se encuentran con una externa realidad con la que tienen que contar. «Estructura y tradición no son sino diferentes aspectos de un sólo complejo cultural que de- 


\section{Fernando Chueca Goitia}

termina lo que es característico y peculiar a la ciudad y la distingue de la aldea y de la vida del campo».

Estos conceptos de Park recogen la tesis, que pudiéramos llamar animista, de Spengler y avanzan sobre ella desde el momento en que tienen en cuenta en su justo valor la importancia de las estructuras materiales en la realidad total que es una ciudad. Park postula con acierto la articulación dinámica de los diferentes aspectos materiales y espirituales que concurren a determinar lo que es característico y peculiar a la ciudad, pero se detiene al llegar a la formulación de cual es la naturaleza de ese complejo cultural que determina precisamente lo que es característico y peculiar. En ella ha de estar, pues, la realidad radical de una ciudad, de la cual todos los múltiples aspectos son realidades radicantes. Por ese camino llegamos nosotros a afirmar que esa realidad radical no es otra ni puede ser otra que la historia, que la ciudad no es sólo estructura ni sólo espíritu, sino una realidad que abraza ambos componentes, su ser físico y su ser moral conjugados en una realidad superior: su ser histórico.

Si las ciudades más que ligadas a la historia son historia ellas mismas, esto nos explicará mucho de su realidad. Vamos a abordar un punto concreto a la luz de esta evidencia nuestra de que la ciudad es, en última instancia, historia. Es éste el de la ciudad como obra de arte. ¿Es o no es la ciudad una obra de arte? Ya hemos visto cómo durante los siglos XVII y XVIII se intenta racionalizar la ciudad, convertirla en artefacto, en algo racionalmente pensado y dispuesto por la voluntad humana. Bajo esta pretensión, y solo bajo ella, puede considerarse la ciudad como una verdadera obra de arte, ya que no puede considerarse creación artística sino aquella que proviene de la voluntad humana claramente definida. La obra de arte no se entiende sin el artista.

Pero esto, esta pretensión de convertir la ciudad en obra de arte, no alcanza más que a determinadas fases del acontecer humano. La ciudad en su integridad es muy pocas veces obra de una voluntad previamente establecida, y cuando esta voluntad llega a imponer un determinado sello, lo hace generalmente de una manera fragmentaria y episódica. Apenas cuando han empezado a materializarse estructuras que reflejaban los ideales de unos hombres o de una sociedad, estos hombres y esta ciudad eran ya cosa pasada y sus ideales se habían ido con ellos, sustituidos por otros nuevos. Existe casi siempre un defasage entre los ideales de cualquier género (religiosos, sociales, políticos, etc.) y su expresión artística. En una palabra: la ciudad es siempre antigua. Esto ya lo vio sagazmente Julián Marías, que considera a la ciudad, por ser artística, expresiva de un estilo, de una estructura 
de alma, pero haciendo una salvedad, que es la que sobre todo nos interesa: «Pero hay que agregar una nota importante: la ciudad, que tarda en hacerse - por eso no es caprichosa-dura mucho tiempo; excepto en su fase de fundación, cuando todavía no es ciudad, es siempre antigua. Normalmente el individuo vive en una ciudad que no han hecho sus coetáneos, sino sus antepasados; es cierto que la transforma y modifica, sobre todo la usa a su manera, descubriendo en ello su vocación peculiar; pero por lo pronto es una realidad, recibida, heredada, histórica. (Este último subrayado es mío). Es decir, ni más ni menos que la sociedad misma. Por eso es difícil de entender; por eso es profunda, radicalmente reveladora».

En una palabra, la forma de una ciudad permanece cuando la sustancia social que le dio vida ha desaparecido. Por eso, formalmente, la ciudad es también historia en sí misma. La ciudad en que vivimos tiene siempre un carácter de reliquia. La ciudad más profana es en alguna medida el lugar sagrado donde se da culto a los antepasados. Pero desde el punto de vista artístico, este constante suceder que es la ciudad misma no permite que se produzca con el debido sosiego la maduración de la obra plástica. La ciudad siempre ha sido y será, por índole de su esencia, artísticamente fragmentaria, tumultuosa e inacabada. No encontramos en ella esa forma definitiva y redonda que ansía el sentimiento estético. Por eso toda ciudad es, estéticamente hablando, una frustración. El hombre que ha conseguido realizaciones tan perfectas en el campo de la belleza, no ha conseguido crear la ciudad bella, a pesar de tantos y tan ingentes esfuerzos. Esto lo percibe cualquier espíritu sensible, cualquier temperamento estético que viaje y recorra las ciudades del globo. Unas más y otras menos, todas dejan en su ánimo, al final, una penosa insatisfacción.

Esta insatisfacción se produce porque si bien se trata de un fenómenos artístico, éste se halla supeditado a pulsación histórica. Es un fenómeno artístico en cuanto que es expresión en cada momento de una realidad social. Pero el constante cambio de ésta, bien sea por evolución o salto, no permite que se produzca el equilibrio requerido en toda creación estética. Las estructuras urbanas, y conste que al hablar de estructuras nos referimos tanto a las externas como a las internas, son constantemente intervenidas, zarandeadas casi, por la pulsación histórica, detrás de la cual van arrastradas con más o menos decalage. En síntesis, podría decirse que la ciudad participa del espíritu artístico, sin llegar a ser, sin embargo, una obra de arte. Si lo fuera en un sentido plenario, dejaría de ser lo que radicalmente es: historia. «Cuando contemplamos algo desde un punto de vista estético - ha dicho 


\section{Fernando Chueca Goitia}

Simmel-, deseamos que las fuerzas opuestas de la realidad lleguen a un equilibrio cualquiera, que se haga un armisticio entre lo alto y lo bajo. Pero contra este deseo de una forma permanente se rebela el proceso moral del alma, con su incesante subir y bajar, con la continua prolongación de sus límites, con la inagotabilidad de las fuerzas contrarias que en él juegan».

Más cerca está la ciudad del proceso moral que del proceso artístico. Su extremada dependencia del hombre, como dijimos en un principio, de su inquietud, que no admite reposo, le impiden permanecer en las sosegadas riberas donde florece el arte.

En una ciudad podrán existir edificios que sean obras de arte magníficas; acaso barrios completos, que hayan logrado la permanencia y estabilidad de una ciudad estilística completa; pero la ciudad en su conjunto, expresión de la inestabilidad y fluencia del alma colectiva, nunca alcanzará rango de obra de arte. En los contados casos que esto no sucede es porque se trata de ciudades muertas, preservadas artificialmente. Las ciudades alcanzan su condición de obras de arte sólo cuando mueren. Les pasa lo que a las personas de vida agitada, martirizadas por el sufrimiento, cuyos rasgos se embellecen con la serenidad de la muerte.

Cuando la ciencia histórica ha ido renovando sus conceptos, cuando sus métodos se han ido perfeccionando y su campo se ha ido ensanchando y profundizando, se ha despertado paralelamente una nueva percepción de la ciudad como hecho histórico, porque si se trata por esencia de un organismo histórico, es también un documento, un depósito, el más formidable, de lo que el acontecer humano va dejando sobre ella en lenta y continua sedimentación. De las ciudades se veía hasta hace poco los monumentos señeros y venerables, las cumbres de la orografía urbana, las catedrales, los palacios, los monumentos conmemorativos. Esto correspondía perfectamente con una idea de la historia como contienda y faena de unas grandes personalidades dominantes, que decidían entre sí el destino humano. Pero ya la mentalidad actual no se satisface con visión tan simplista, y al tratar de discernir las características de una civilización, no podemos confinar nuestra atención al estudio de los poderosos. Debemos conocer la situación del pueblo, sus formas de vida y sus creencias, la índole de las instituciones creadas por la sociedad, el desarrollo de la cultura y el sentido de la misma, es decir, el panorama completo de la vida y no las cimas que sobresalen.

$\mathrm{Al}$ estado llano de la historia corresponden en la ciudad las casas vulgares, que se apiñan unas a otras en formas expresivas, lo mismo que los monumentos singulares representan las personalidades diri- 
Riesgo y desgracia de las ciudades históricas

gentes. Separar, por consiguiente, el palacio de las casas burguesas o de las populares, es como remover una frase de su contexto.

El llevar al estudio de las estructuras materiales que componen la faz o rostro de la ciudad un criterio puramente artístico, es lo que condujo a esta artificial escisión que destacó los edificios monumentales, o a lo sumo los barrios antiguos más caracterizados, de la gran masa de edificación de acompañamiento, que quedó en la sombra, olvidada, como algo inerte que carecía de expresión. Falta de expresión artística, tal vez, pero en ningún caso de expresión histórica. El enfocar, en cambio, el estudio de la ciudad desde su esencia histórica, operación que puede ser mucho más fecunda en resultados, nos evitará amputaciones injustificadas y una integral percepción del fenómeno urbano, cada vez más acuciante a la vista del desarrollo que va tomando en nuestros días el urbanismo.

Partiendo de la base firme de la realidad histórica de la ciudad, nada de lo que a ella se refiere, aún lo más insignificante, deja de ser revelador; todo constituye parte de una totalidad imposible de disociar. Lo que artísticamente puede resultar mudo, históricamente será, acaso, elocuentísimo. No hay que olvidar que la ciudad es por sí misma un formidable archivo de recuerdos. En la urbe se condensan, no sólo en el espacio, sino, en el tiempo, los hechos y las vidas humanas más significativas. Este grado de condensación preserva su recuerdo, de la misma manera que un archivo, al reunir papeles que provienen de muy diversos orígenes, asegura su conservación. Es indudable que si todos aquellos acontecimientos y aquellas vidas no hubieran sucedido en la ciudad, no hubieran tenido su referencia a ella, su memoria habríase desvanecido mucho más fácilmente. Es la condensación de su propia salvaguardia.

Si deambulamos por París, podemos hallar el lugar donde Enrique IV fue asesinado; la elegante plaza donde vivía Richelieu, en un ambiente del París de los Mosqueteros; el pasamanos donde se posaba la mano de Voltaire; el ala del Louvre donde se reunió la Convención. Podemos seguir el itinerario de Bonaparte, casi niño, desde la diligencia que lo trajo a París hasta la Escuela Militar; el pequeño laboratorio donde empezaron a trabajar los esposos Curie, etc.

Una plaza de Madrid evoca todavía la sombra de Cisneros; en la calle Mayor, aunque transformada, cada adoquín levanta el eco de las pisadas de Lope, de Tirso, de Calderón de Villamediana; en la Casa de Panadería, Goya, a los diecisiete años, sufrió los primeros reveses académicos; privado de ambiente, pero conservado como reliquia, un arco de ladrillo es el mudo testigo de hazañas patrióticas; al pasar 


\section{Fernando Chueca Goitia}

por determinada calle céntrica parece sonar el estampido de los arcabuces criminales; en tal palacio, hace pocos años dejaba este mundo una emperatriz... Eso son las ciudades; escenario de la historia, la grande, la pequeña, la local, la nacional, la universal; los hombres vienen de muy diversas partes, de aldeas, de villorrios distantes; los acontecimientos se fraguan en el difuso mundo, pero siempre la ciudad es punto de convergencia, lugar de la acción, donde todos los procesos se comprimen, se esquematizan y aceleran; horno de combustión social. Queda luego el recuerdo, y la ciudad se convierte en archivo.

$\mathrm{Al}$ irse imponiendo, cada vez con más fuerza, la conciencia de que esto es así, la ciudad va reverdeciendo sus recuerdos y en algunos casos señalándolos al viandante por medio de lápidas. La lápida parece que va dirigida en primer lugar a honrar la memoria de algún héroe o personalidad sobresaliente. Pero este movimiento de ida supone otro de vuelta: al honrar hazañas, héroes o simples acontecimientos, lo que se hace es conmemorarlos, es decir, recordarlos en común, hacerlos material de autoconciencia colectiva. La lápida va dirigida tanto a exaltar la hazaña o al héroe como a buscar la satisfacción de los que la promueven y colocan. La ciudad que con más entusiasmo va lapidando sus muros es la ciudad que más gusto obtiene golpeando su dormida conciencia. Este tema merecería una extensión mayor que no cabe dados los límites a que ahora debemos sujetarnos. Pero baste decir que el afán lapidario coincide con el despertar de la conciencia histórica en el siglo XIX, con el vago presentimiento de que la ciudad es un archivo al que, a su modo, es necesario clasificar y poner etiquetas, que en este caso serían las lápidas.

Las lápidas revelan, pues, que esta conciencia existe, que algo de lo que es interior, el alma, sale a la superficie en forma de placas blancas, cristalizada expresión de una misteriosa química social. ¿Podríamos concebir ahora la ciudad sin esa conciencia histórica? O dicho de un modo más directo, ¿podríamos vivir sin ciudades que fueran, a la vez, laboratorio y archivo de ella? Sin duda, no. La civilización es difícil, casi imposible, concebirla sin ciudades, y las ciudades, sin estos atributos. Es cierto que existen y han existido aglomeraciones humanas que han carecido de ellos pero, como ya hemos insistido antes, esas aglomeraciones no son lo que a primera vista parecen, y aunque grandes, pueden no ser más que formas de ruralismo disfrazadas, o por otro lado escuetas conurbaciones industriales. La aldea pertenece todavía al medio natural; es naturaleza, sin más, como la ciudad es historia. El asentamiento industrial es prolongación de la fábrica $\mathrm{y}$, como ella, simple instrumento de la producción. También 
se nos dirá que la ciudad en su fase de fundación carece, naturalmente, de historia; pero es que entonces no es todavía ciudad en un sentido plenario, no ha llegado a la edad adulta. Sólo en las ciudades antiguas el propio ritual sagrado de la fundación les conferiría aquellas virtudes que otras debían ir ganando poco a poco, en un lento proceso de maduración.

Cuando decimos, pues, que la civilización no la concebimos sin ciudades nos referimos a las que son de por sí un mundo completo y gozan de todos los atributos inherentes a su condición. Entre ellas y todo lo que no es ciudad se establecerán delicadas relaciones mutuas. Esta es otra cuestión que ahora no importa a nuestro caso y que no empiece el carácter decisivo - no exclusivo- de aquellas en la construcción de la sociedad humana.

«La razón de que las ciudades sean decisivas en toda sociedad, hasta en las de predominio rural - ha dicho Julián Marías- es que son el órgano de la socialización o, si se prefiere, de la sociabilidad. Una sociedad es sociedad y, sobre todo, es una, gracias a sus ciudades». Las ciudades, pues, como tales, en plenitud de sus atributos, son insustituibles en nuestra sociedad. Puede vivirse fuera de ellas, pero siempre contando con ellas, con un apoyo y especial referencia en ellas. Incluso al hombre de la aldea más remota, y sin que se de clara cuenta de ello, puede llegar el consuelo de que existen Roma, París, Pekín o Filadelfia y que en ellas se guarda un sagrado depósito de la humanidad. Porque la ciudad es una aglomeración humana fundada en un solar convertido en patria y cuyas estructuras internas $y$ externas se constituyen y desarrollan por obra de la historia, para satisfacer y expresar las aspiraciones de la vida colectiva, no sólo la que en ellas transcurre, sino la de la humanidad en general. Esta es una definición que me atrevo, modestamente, a proponer.

Últimamente he tenido ocasión de parar unos días en una ciudad tan alejada de nuestra civilización como Pekín, capital de la inmensa China y he podido contemplar con asombro los monumentales restigios de su pasado imperial, sobre todo el fabuloso palacio de los antiguos emperadores, lo que se llama la Ciudad Prohibida. Su magnitud, su simetría, la mayestática ordenación de sus templos y diversos pabellones áulicos no pueden por menos de sorprender al visitante. Allí sigue resonando la historia con sones grandiosos.

\section{La ciudad amenazada}

El problema es de una gravedad extraordinaria. Es acuciante para todo el viejo mundo y parte del nuevo cuando éste recibió, como le 
sucedió a Hispanoamérica, un legado cultural que fue proyección de la civilización europea a través del filtro de la hispánica. Sin embargo, ¿qué queda de Méjico, de Lima, de Caracas, de Quito, de Salta, de tantas ciudades nobilísimas que honraban a todo un proceso civilizador? Casi nada. De sus expoliados conjuntos se eleva el lúgubre sonido de un réquiem acongojante.

Nosotros podríamos dolernos de la ingratitud de nuestros hijos y tendríamos autoridad para hacerlo, si por nuestra parte hubiéramos dado el ejemplo. Pero está ya sucediendo todo lo contrario. Somos nosotros los que nos estamos americanizando en el peor sentido de la palabra y dando con nuestro proceder razón a su insensatez.

La sociedad española de hoy, que por una parte regala sus oídos con slogans patrióticos del más caduco estilo, por otro niega lo que dice con sus obras vandálicas. Obras son amores y no buenas razones, y con nuestras obras estamos negando mucho de lo que decimos. Al final se cumplirá aquello de que por sus obras los conoceréis.

Lo hemos dicho en repetidas ocasiones, en libros, en artículos, en conferencias, en conversaciones privadas e informes técnicos y académicos; nos acongoja el grado de indiferencia de la sociedad de hoy por todo lo que supone valores de espíritu, de la cultura, del arte, de la tradición, de la esencia histórica y racial del mundo nuestro, humano, geográfico, paisajístico. Parece que sobre España ha caído una población desarraigada y nueva, indiferente a todo, sin conexiones ni línea de continuidad con el pasado. En suma, como una sociedad extranjera que ocupara una casa que no es la de sus antepasados y que hace almoneda de ella, con la crueldad de un rapaz apetito económico. La sociedad española actual parece decir: iqué se me da de todo esto que he heredado y con lo que no tengo nada que ver! ¿Vale acaso para venderlo? Pues a venderlo y que los americanos, o quienes sean, se lleven nuestros retablos, nuestros cuadros, nuestros enseres viejos y nos den dólares con que adquirir los gadgets excitantes de un mundo tecnológico ante el que nos postramos en adoración como nuevos salvajes. Al hombre que hoy, en el que prevalece cuantitativamente, el tan traído y llevado hombre-masa, a ese que corre desolado en automóvil lanzando miradas aviesas, cargadas de cómicas y desproporcionadas amenazas, le importa un bledo, entre otras cosas, la ciudad que ha heredado. Es más, comprende la ciudad como un obstáculo y ve con alegría que el obstáculo caiga y deje su vía expedita, una vía que ni él mismo sabe a dónde conduce. Este plebiscito latente por el que la mayoría condena a la ciudad sin saber lo que es y lo que significa, es el que puede terminar con una de nuestras mayores 


\section{Riesgo y desgracia de las ciudades históricas}

riquezas espirituales y con uno de los más frágiles depósitos que una civilización multisecular e ininterrumpida ha puesto en nuestras manos.

El sistema de neutralizar en lo posible a este hombre-masa, envenenado a conciencia por una serie de mitos que parpadean ante sus ojos como los espejuelos con que se compraba la voluntad y la riqueza de los salvajes, no es otro sino el de la educación. El sistema es lento, pero la humanidad desde tiempo inmemorial no ha encontrado otro.

Pero a esto volveremos después. Ahora vamos a ver cómo actúa este hombre-masa. Lo primero que hay que decir es que este hombre-masa no se reduce a ciertos estamentos clasistas, a ciertas clasificaciones socio-económicas que se habían concretado en la figura del proletario clásico. Ahora toda la sociedad de arriba abajo actúa con los apetitos del hombre-masa y desde luego con un primigenio y tosco sistema de valores.

Ortega describió con pincelada enérgica una sociedad de este tipo cuando se enfrentó hace ya muchos años con la de una de estas grandes metrópolis modernas: Buenos Aires. «En Corrientes y en las calles próximas llenas de bancos y oficinas, es donde pulsa esa fauna atroz de factoría. Son los hombres que han venido a lo suyo, de apetito urgente, que al pasar os desarticulan el hombro porque van disparados a ultimar sus negocios. De imaginación seca, su hambre es tanto más feroz porque no desean cosas que ellos hayan imaginado y tendrían que crear, sino lo que está ahí, en el escaparate. Necesitan comìnar un automóvil, una vitrola, una radio y un frigidaire. Para tan concreto menester están espléndidamente dotados con las tres cualidades necesarias: audacia, grosería y prisa».

No nos engañemos, este tipo de sociedad es el que ha ascendido al primer plano de nuestro mundo de hoy; esta sociedad es la que tiene el papel de protagonista, la que tiñe todo, impone sus gustos y comportamiento, crea el clima actual y da la pauta de todo.

¿Quién se opone a la empresa bancaria que a su insolencia une su riqueza y su poder; quién se opone, incluso, al más modesto comerciante que mide sus apetencias por la longitud de sus escaparates y por el brillo opalino de sus tubos fluorescentes, uno de tantos espejuelos del progreso para los pueblos débiles que ya no creen en sí mismos?

Esta mentalidad de hombre-masa trasciende a todos los estamentos y clases, es la que tiene el aristócrata, que trata por todos los medios de enajenar en el mercado internacional el Greco o el Goya que tuvo la inmerecida fortuna de heredar, que derriba su palacio para transformarlo en solar, verdadera piedra filosofal de la alquimia moderna, que ha convertido en. realidad un añejo sueño: transformar la piedra o la arcilla en oro. 
Esta mentalidad es la que tiene el alto clero que aprovecha las disposiciones conciliares pro-domo-sua y que aunque parezca mentira es uno de los más típicos hombres-masa de nuestro tiempo. ¡Qué amarga experiencia ha tenido uno discutiendo con prelados, canónigos, arciprestes, que se han escandalizado porque hemos defendido una iglesia barroca, un retablo o unos sólidos y nobles bancos de iglesia! Su argumento de siempre: ¿Pero que valor da usted a esto si no es más que una antigualla? A mi lo que me interesa es poner calefacción en la iglesia y abrir una cafetería en el centro parroquial. Y luego hemos visto esos retablos, esas imágenes, esos bancos, en el anticuario más próximo. Porque en el fondo, aun engañándose a sí mismos, se dan cuenta que tienen un valor, pero claro está, un valor traducible a dinero. Es que en ellos ha encarnado, como en los antiguos poderes maléficos, el hombre-masa.

Esta mentalidad es la que tiene el político ansioso de éxitos fáciles y populares, vasallo fiel de los grupos de presión que de manera pertinaz y constante mandan desde la sombra. El político complaciente que no quiere problemas, que no quiere enfrentamientos, que desea ver pasar sus días, cuantos más mejor, en la cómoda poltrona. El político muchas veces cargado de buenas intenciones, pero paralizado por una maraña de intereses que al final le entregan al dolce far niente. $\mathrm{Y}$ el dejar de hacer, en este caso equivale a dejar que se haga lo que no se debe de hacer. ¡Ah!, pero es irremediable... es el signo de los tiempos, no podemos oponernos al mundo que vivimos. Vivimos en el siglo XX. Con este cómodo ropaje de pretextos, al parecer tan plausibles, cuántos egoísmos se esconden.

La misma mentalidad de hombre-masa, de apetito urgente y perentorio, tiene el técnico de nuestros días. Pero, además, ese técnico tiene unas armas infalibles. Vivimos en plena tecnolatría; cuando nos encontramos sin recursos espirituales, sin una verdadera conciencia de ser, sin anhelos comunes, sin programas de acción colectiva, apelamos como mágico recurso a la técnica. Gobiernos de tecnócratas son la panacea de los tiempos difíciles y aunque el técnico nos lleve a la devaluación o a la crisis, el técnico jamás se ha equivocado. Él tiene siempre la respuesta altiva y estoica de un Felipe II en el naufragio de la Invencible: "Yo no envié la armada a luchar contra los elementos». Un técnico economista cómo va a descender, por ejemplo, a consultar el buen sentido y la sana experiencia de un agricultor curtido en el contacto con la tierra, cuando tiene que crear sus esquemas planificadores, cargados de ciencia libresca.

En otro lugar dije que si a la condición de técnico se suma la de burócrata, obtendremos un centauro en el que se unirán la autoesti- 


\section{Riesgo y desgracia de las ciudades históricas}

mación y la fuerza ejecutiva. Este híbrido no condescenderá fácilmente al diálogo ni dejará que nadie influya en sus determinaciones. Salvemos todas las honrosísimas excepciones que ustedes quieran, pero ese técnico egocéntrico cada día abunda más y cada día influye más en el comportamiento del conjunto.

Hoy en día se ha dado un caso muy curioso y que vale la pena analizar. En los países, sobre todo autoritarios, el técnico ha sustituido al intelectual. El intelectual es un ser peligroso por la sencilla razón de que el intelectual piensa, y líbrenos Dios de la funesta manía de pensar. El intelectual piensa y el intelectual se equivoca y es él mismo el que lo reconoce; he aquí su grandeza. El técnico no piensa; no es ésa su misión; el técnico aplica fórmulas que no ha tenido la necesidad de pensar, que ha aceptado con una reverencia fanática basada en su sistema de mitos, axiomas y tabús.

El carácter axiomático del técnico no produce ninguna inquietud en el político, no le sumerge en un mundo fluido y variable como el del intelectual. El técnico le da las cosas hechas y le sirve de inapreciable escudo. Con él está tranquilo.

En materia de actuación municipal las autoridades tienen a su servicio unos técnicos impagables. Son los urbanistas. Si un alcalde tiene un urbanista o unos urbanistas a su lado, tiene siempre la espalda cubierta. "Lo han dicho los técnicos, he seguido el informe de los técnicos, los técnicos no pueden equivocarse». Los técnicos no necesitan explicar lo que hacen, no pueden descender al diálogo con el común de los mortales, ellos están ahí como el mago de la tribu, para inspirar la acción de los políticos y con este hábil binomio se elude todo el problema de opinión pública.

Otro hombre-masa de nuestro tiempo es el periodista, el periodista simplón e ingenuo en el mejor de los casos, que sigue con la mayor docilidad los slogans imperantes. El que apostilla las providenciales medidas de los dirigentes, de los políticos, de los tecnócratas que van a construirnos un mundo feliz y progresivo. Se entusiasmarán y nos anunciarán la alegre nueva de ese viejo caserón que desaparece, de esa gran vía que se abre, de ese polígono que va a resolver el problema de la vivienda, aunque ese polígono esté planteado con los pies y carezca de todo sentido urbanístico, etc.

He apuntado solamente algunos de esos tipos sociales de hombre-masa que constituyen la inmensa mayoría de nuestra sociedad. Podríamos añadir otros muchos, sobre todo en el vasto campo de los especuladores, de los promotores, de los agiotistas, etc., pero esto basta para darnos cuenta de en que manos está el porvenir de nuestras ciudades. 
Ahora que estamos a punto de terminar una centuria, el siglo XX y vamos a pasar al siglo XXI el panorama se nos presenta todavía más incierto.

Antes de que en España se estructurara en régimen de autonomías, la defensa de las ciudades históricas se reducía a las escasas posiblidades de una Dirección General de Bellas Artes. Pero, ¿que era la Dirección General de Bellas Artes? Sencillamente un fenómeno residual, una especie de momia burocrática. La Dirección General de Bellas Artes así constituida estaba bien para una España de 1920. Entonces nuestras grandes ciudades no pasaban de 700.000 habitantes. En nuestro país no se había producido la explosión demográfica, ni el éxodo del campo, ni la congestión de las grandes urbes. La Revolución Industrial era una cosa que se estudiaba en los libros pero que no había pasado nuestras fronteras. El Director General tenía a su cargo unos pocos museos, algunas escuelas de artes y oficios y la custodia de unos pocos monumentos de venerable antigüedad y prestigio arqueológico. Todo era fácil, sencillo, modesto. Pero de repente esta pequeña máquina administrativa tiene que enfrentarse con una alud: ciudades que crecen vertiginosamente, una historia que se desintegra y que naufraga, monumentos del pasado que se arrasan, invasiones turísticas que hay que canalizar y orientar, exigencias artísticas nuevas y que rebasan los viejos cuadros de los eruditos de antaño, masas de estudiantes descontentos que no encuentran una enseñanza dotada, ágil, viva y con prestigio.

Por si esto fuera poco se ha producido un cambio radical en la estructura de la administración del Estado al semifederarse España bajo el Sistema de las Autonomías. El Estado central ha cedido muchas de sus potestades a las autonomías regionales y provinciales y lo primero que pensó en ceder, por no considerarlo capital, fue todo lo referente a cultura y patrimonio artístico.

Por lo tanto actualmente el Director General de Bellas Artes hace la más triste figura en la administración del Estado, privado de casi todas las competencias de antaño y vagando como un fantasma, como una sombra de sí mismo.

Esta crisis de autoridad hace que los que defienden estos valores lo hagan siempre con timidez, con miedo, con subterfugios, para no despertar las iras de los poderosos y no pasar por ingenuos y rezagados. Todo se pide por favor, como por lástima, poniendo por delante unas afirmaciones que no se sienten. "Sí, verás, estamos de acuerdo, lo importante es lo importante, pero si pudiéramos salvar esta portada, al menos». Y se apunta el deseo casi con rubor. Este estado de cosas, francamente, no puede seguir así. 
Tan caducos y tan fósiles como el organismo central, son los organismos dependientes: unas tristes Comisiones de Monumentos, que casi sepultadas se intenta en parte resucitar. Pero los que las componen no participan del espíritu moderno que deben tener hoy estas instituciones. Son historiadores, eruditos locales, arqueólogos, profesores que, sin visión de los problemas de nuestra época, y sin fuerza para enfrentarse con ellos, se refugian en sus bibliotecas, en sus archivos, en sus museos y en el mejor de los casos, publican una revista erudita que sólo leen entre ellos. Yo tengo el máximo respeto para el erudito local, entre otras cosas porque está desapareciendo y es una pieza fundamental de nuestra cultura, pero su misión es otra. Puestos a luchar yo recuerdo la insolencia de Don Juan Tenorio cuando ante las amonestaciones de Don Diego y de Don Gonzalo, dijo soltando una carcajada: "es venir a amenazar a un león con un mal palo».

Los arqueólogos especialmente me dan miedo. Suelen tener una deformación profesional que les lleva a conformarse con rescatar alguna piedra vieja, algún capitel que llevar a su museo; cuando no a derribar un edificio con la esperanza de excavar un zona de presunto interés arqueológico.

Lo mismo que decimos de las Comisiones de Monumentos, podemos decir de las Academias. Cuerpos venerables pero constantemente desoídos y virtualmente inoperantes. Doctas instituciones que vacilan entre mantener un crédito salvando las apariencias y correr el riesgo de ser cada vez más postergadas.

Yo quisiera decir algo también sobre los arquitectos encargados de velar por los monumentos y por los conjuntos histórico-artísticos. No me refiero a los arquitectos que están del lado del enemigo, a ésos, ya damos por supuesto que lo que les interesa es demoler para poder construir y las más de las veces para construir a favor de la corriente. Me refiero ahora a los otros, a los que están del lado de aquí de las líneas, a los llamados arquitectos conservadores. Lo primero que hay que decir, es que son pocos, poquísimos. En un país en donde la tarea es tan ingente, tan fabulosa, se puede decir que se cuentan con los dedos. Algunos provienen de los viejos cuadros y entre ellos hay figuras estimabilísimas y con una larga ejecutoria que les honra. De otros no podemos decir lo mismo, pues nunca han demostrado ni una verdadera maestría, ni una verdadera devoción. Otros han llegado un poco al azar y han ocupado estos puestos lo mismo que podían haber ocupado otros escalafones profesionales. El equipo es en suma tan escaso como poco cualificado. Hoy en día se han incorporado a estos menesteres algunos jóvenes, entre los que existen personas valiosísimas, competentes y animosas. Pero lo que más nos preocupa es que, como 
tantas veces en la vida española, no se produzca la selección a la inversa, que los mejores no se desanimen ante un clima hostil, ante las marrullerías de la sociedad con la que tiene que luchar, ante el escepticismo de sus mayores que les deben servir de ejemplo y de respaldo, y queden luego los acomodaticios que a todo se pliegan y en todas las aguas navegan.

Pero ¿cómo vamos a impulsar a los jóvenes para que se entreguen a un cometido que tan pocas posibilidades les ofrece y en el que tantos sinsabores les esperan? Lo primero que no podemos ofrecer a estos jóvenes es una adecuada formación. Las Escuelas de Arquitectura de España son en todo el mundo las que dedican menos atención a las enseñanzas humanísticas, históricas y artísticas. Parece inverosímil en un país de nuestra riqueza monumental, de nuestro pasado y de nuestra personalidad, pero es así y de una manera flagrante.

En toda la carrera de arquitecto no hay sino dos desmedradas asignaturas: una de Historia del Arte en general, que no llega ni a ser una visión cinematográfica, y otra de Historia de la Arquitectura. En el plan de 1957 se incluyó un intento de diversificación creándose unas especialidades: urbanismo, cálculo y estructuras y arquitectura histórica y restauración de monumentos. Pero luego el propio Estado considero que esto era superfluo y ha suprimido las especialidades. El preparar a los futuros conservadores y restauradores es algo que a nuestro Estado no le preocupa, es por lo visto baladí y superfetatorio. Por todos los lados recaemos en lo mismo, el desinterés total, la falta de conciencia de nuestro ser histórico.

Si ya en la Escuela el joven aspirante a arquitecto se da cuenta del poco valor que se da a estas cosas, ¿qué podemos pedir a esas promociones que luego se extienden por todos los pueblos y las ciudades de España para ejercer su profesión? ¿Qué ejemplo y qué enseñanza les damos? ¿Qué valor van a dar luego a unos monumentos, a una historia, a un pasado que no conocen ni de oídas?

Creo que no vale la pena insistir. Ya hemos pasado revista a los dos ejércitos contendientes. ¿Cómo nos va a extrañar la victoria del uno y la derrota estrepitosa del otro?

Pero, sin embargo, es tarea de todos intentar en la medida de nuestras fuerzas, si no de golpe, al menos poco a poco, equilibrar las fuerzas en pugna. Hacer que disminuya y se debilite un ejército y que crezca y se fortalezca el otro. ¿Es tarea difícil, acaso imposible? No lo se. Pero soy de los que creen que lo primero para atajar un mal es analizarlo, hacer el diagnóstico, aunque sea cruel, para luego poner el remedio. Ese remedio que nos debe conducir a establecer el decálogo al que acabamos de hacer mención al final del capítulo anterior. 
Riesgo y desgracia de las ciudades históricas

Si esta carta o decálogo llegara un día a ser suscrita por todos los alcaldes de España, ése sería un día de júbilo para los que creemos en el futuro de España, pero, jay!, lo vemos tan lejano que nos parece un sueño, una utopía inalcanzable.

\section{Aumentan los Riesgos}

Estos riesgos a los que nos venimos refiriendo aumentan con el contagio que las grandes urbes, donde toda modernidad tiene su asiento, y toda especulación su territorio. Luego llegan a los pueblos, villas y pequeñas ciudades, llenas de carácter y dónde prevalece una arquitectura típica de índole regional.

En primer lugar, ¿qué quiere decir arquitectura típica regional? Esto es interesante, porque acostumbramos a enunciar determinados conceptos de una manera rutinaria y sin hacernos cuestión de ellos. Vagamente intuimos que se trata de una arquitectura que vemos por los pueblos, en lo poco que va quedando de un escenario tradicional cada vez más erosionado y descoyuntado, una arquitectura de materiales naturales, piedra, barro, madera, que nace del propio terruño que la sustenta y que de vez en cuando se expresa por las notas pintorescas de un portalón claveteado, una reja de sabrosa forma, una alegre solana o un atrevido alero. Y con esto nos quedamos conformes sin profundizar más, dando por descontado que ya sabemos a lo que nos referimos cuando hablamos de arquitectura típica regional. No digo, ni mucho menos, que esto no sea así, pero hay que profundizar más. Porque el discurrir sobre el tema ya es de por sí esclarecerlo. Empecemos por la palabra típica. Se trata en efecto de una arquitectura típica, es decir, que obedece a tipos. Esto es, etimológicamente, lo que la palabra significa; pero esta palabra, degenerándose, ha conducido a la noción del tipismo y al hablar del tipismo dejamos muy atrás algo que para recobrarlo nos empuja a buscar ciertos neologismos como tipificación y tipología y si apuramos más la cosa llegaríamos a normalización o estandarización. Entonces caemos en la paradoja de considerar que la arquitectura típica es todo lo contrario de una arquitectura tipológica o normalizada.

La degeneración de la palabra típico nos ha puesto en el trance de equiparar arquitectura típica a arquitectura versátil, caprichosa, anecdótica y pintoresca. Arquitectura que en lugar de ser rigurosamente típica, nacida de una profunda motivación, es una fantasía pintoresca producto de un tipismo o folklorismo trivial. En nuestro caso sería el correlato arquitectónico de la España de pandereta, de la typical Spain. 
Esto parece que no, pero tiene su importancia porque hay muchas gentes, entre las que naturalmente no faltan los arquitectos, que desprecian esta arquitectura por considerarla poco seria, folklórica en el mal sentido de la palabra y hasta si se quiere definitoria de una situación de subdesarrollo, como ahora se dice.

Ya hace mucho tiempo, cuando la Dirección de Regiones Devastadas sentó los criterios de reconstrucción de los pueblos asolados por la guerra, muchos se le echaron encima acusándola de realizar pueblecitos típicos, muy monos y arregladitos en los que no faltaba el farolito de marras o la reja andaluza. Se le acusó, no sin cierta razón, de realizar pastiches folklóricos, que nada tenían que ver con la dignidad de los pueblos castellanos, aragoneses o andaluces. Quizá sí, quizá hubo algo de esto, pero también es necesario revisar algunas de estas críticas si queremos ser justos. La verdad es que los pueblos «reconstruidos» por Regiones Devastadas, aunque sean un poquito almibarados, no han dañado nunca a nuestro paisaje ni han distorsionado el carácter de nuestros pueblos como tantas cosas que se han hecho luego. El principal defecto que pondríamos a la labor de Regiones Devastadas no es tanto de orden estético como de orden constructivo. Los nuevos pueblos están mal construidos, con materiales a veces deleznables, con carpinterías sórdidas, con hierros endebles, y entonces al folklore se une a veces la pacotilla y adquieren aspecto de decorados de teatro o de cine. Luego hablaremos también de que la arquitectura típica no puede traducirse a módulos o a dimensiones que no son las suyas, porque entonces el falso mimetismo resulta un caso desolador de quiero y no puedo.

Pero ahora no nos desviemos de nuestro tema y sigamos con nuestra argumentación que no es otra sino volver a incidir en el auténtico tipismo de esta arquitectura. Pensemos que cuando decimos típica es por algo, porque obedece a tipos, en otras palabras porque tiene una tipología específica que le da autenticidad y seriedad, todo lo contrario de ese pintoresquismo trivial a que aludíamos antes, y que a tantos hace sonreír un poco conmiserativamente cuando decimos arquitectura típica. Por otra parte, no olvidemos que decir típico equivale en gran medida a decir auténtico. Lo auténtico es aquello que podemos contrastar con unos patrones o tipos que le otorgan legitimidad. Cuando decimos es un típico asturiano o toledano queremos decir es un asturiano o toledano auténtico, legítimo, por sus rasgos, por su manera de ser, por su carácter, etcétera. Rescatemos, pues, para esta arquitectura que llamamos típica su condición también de auténtica y legítima y empezaremos a sacudir de ella esas apreciaciones peyorativas que la empañan. 
Ahora bien, esta arquitectura es típica no en una forma abstracta, como puede serlo la maison dominó de Le Corbusier, sino en una forma natural que es a su vez una forma regional. Por lo tanto, a esa arquitectura la definen dos adjetivos, típica y regional, que para nosotros son inseparables. También a un tipo humano le da autenticidad el responder a los rasgos raciales de su región y cuanto más responda será más típico, más auténtico, de raza más definida, de mejor casta. La región actúa en la arquitectura un poco de la misma manera, otorgando a ese tipismo una realidad por decirlo así racial, una casta. La arquitectura típica regional es por ende, no puede ser de otro modo, una arquitectura castiza. También al término castizo muchas personas lo toman por mala parte y lo hacen sinónimo de majeza o chulapería o en el mejor de los casos de zarzuelismo verbenero. También parece molestarnos hoy en día que una persona o una cosa sea castiza, porque esto es propio de costumbristas trasnochados, como pueden ser los amantes de la capa o los que rinden culto gastronómico al cocido a la madrileña. Pero la noción de casticismo es algo muy importante como nos lo demostró don Miguel de Unamuno en sus famosos ensayos En torno al casticismo.

A esta arquitectura típica por ser regional le corresponde ser castiza y no demos asustarnos por ello, ya que esto quiere decir que tiene casta. Si es una arquitectura castellana, o más concretamente segoviana, ponemos por caso, es porque obedece a las condiciones naturales, históricas, vitales y temperamentales de esa región de España, como corresponde la raza a la casta de los hombres de dicha región, que son los que la han originado. Por eso su regionalidad es el fundamente de su casta, de su casticismo.

Esta arquitectura es en primer lugar típica, es decir, obediente a normas constantes, no caprichosa ni voluble. La volubilidad es signo de una actividad artística personal, del hacer de un hombre muchas veces deformado por su propia autovaloración individual, pero no cabe en una obra colectiva, como es la que en el curso de los siglos ha dado lugar a la arquitectura típica regional. Ortega y Gasset dijo que el verdadero arquitecto era el pueblo y que la arquitectura era un inmenso gesto social. Esto, que el filósofo lo entendía como aplicable a la arquitectura en general, donde realmente tiene validez absoluta es en la arquitectura popular que es la obra colectiva por excelencia. La arquitectura típica regional es consecuencia de la sabiduría popular, en ese aspecto es puro folklore, otra palabra desvirtuada por el uso. El primero que utilizó esta palabra que tanto éxito había de tener en el curso del tiempo fue el inglés W. J. Thoms en 1846. Folklore 
se compone de los dos términos folk, pueblo, y lore, sabiduría, es decir, sabiduría popular. No hay que confundir la palabra inglesa folklore con la alemana Volskunde. La primera se refiere al saber que tiene el pueblo de las cosas y la segunda a lo que los doctos saben del pueblo, cosa bien distinta. La arquitectura popular es una manifestación del saber del pueblo, puesto que fue el pueblo quien en realidad le dio vida para que sirviera a sus necesidades con los medios y técnicas a su alcance. Es, por lo tanto, folklore en grado sumo, pero tampoco debemos asustarnos de utilizar esta palabra siempre y cuando la purifiquemos recuperando su sentido ordinario.

En suma, la arquitectura típica regional responde a las siguientes notas: $1^{\circ}$, tipismo, en el sentido de norma en vez de volubilidad; $2^{\circ}$, regionalismo y por ende casticismo; $3^{\circ}$, folklorismo en el sentido de que es obra colectiva, anónima, impersonal y que dimana de la sabiduría del pueblo.

Pues bien, si le decimos a un arquitecto joven que defendemos una arquitectura típica, castiza o folklórica, se nos echará a reír y nos mirará con conmiseración, porque ha tomado estas palabras por mala parte, desconociendo su significación originaria y porque sólo le suena la forma degenerada. Pero si le dijéramos que defendemos una arquitectura tipológica dentro del marco de una región natural y concebida por un impulso colectivo primigenio, la cosa le sonará mucho mejor y hasta se entusiasmará con la empresa. Y, sin embargo, es lo mismo pero dicho en castellano castizo, yo diría en un castellano auténtico. Pero a los jóvenes les gustan los neologismos y las perífrasis con saborcillo culturalista, por mucho que a veces y por otros motivos, repugnen también del culturalismo.

Creo, al menos lo creo yo, que no ha sido ocioso empezar por definir qué entendemos por arquitectura típica regional para pasar luego al análisis de cuáles son los factores que más gravemente la amenazan y que en el fondo no son otros sino aquellos que atentan por razones muy varias a las notas que principalmente la caracterizan. En primer lugar su tipismo o su tipologismo. Aunque parezca paradójico, la arquitectura que ahora se hace en los pueblos y que obedece a un mimetismo degenerescente de la que produce el medio urbano es mucho más caprichosa y voluble que la que antes se hacía en los pueblos sin intromisiones de fuera. Ésta sí que carece de tipología porque en lugar de ser obra colectiva es obra individual y por lo común de mediocres personalidades, de personalidades sin personalidad que imitan torpemente y sin criterio lo que para ellos representa un valor activo de primer orden tomando muchas veces el rábano por las hojas, es decir, 


\section{Riesgo y desgracia de las ciudades históricas}

lo más deleznable del diseño moderno, por lo más significativo, lo que solemos llamar modernoso como degeneración de moderno.

Es decir, aunque resulte paradójico, la arquitectura del medio rural tiene una normativa mucho más estricta, producto de la sabiduría popular por su carácter colectivo, que la falsa arquitectura modernosa trasplantada desde el medio urbano al rural y que en el fondo no es más que la arquitectura voluble, mal digerida por unas personalidades mediocres que suelen tener además el complejo de querer afirmar a troche y moche su personalidad para destacar ante sus rústicos vecinos. La estridencia que ha producido constantemente lo que se ha solido llamar épater le bourgeois también la percibimos en esta arquitectura que estamos introduciendo en el medio típico regional y que a menudo apela a las formas, diseños, materiales y colores más estridentes, para épater a los sencillos convecinos dando lustre a la vanidad de propietarios y constructores que no van a quedarse atrás de lo que se hace en Madrid o en Barcelona. Entran aquí, pues, los factores psicológicos que son de suma importancia con relación a lo que venimos analizando.

Parecería lógico que puesto que venimos analizando un caso de invasión, la de la arquitectura a raíz urbana en la arquitectura de raíz regional, esta invasión se produjera sobre la base de una normativa más estricta. Al fin y al cabo la civilización industrial, de la que es espejo la ciudad, se basa, universalmente hablando, en la tipificación, en el estándar, en la producción en serie, en la prefabricación, etc. Lo curioso es que por el momento lo que pasa es absolutamente lo contrario. El producto o mejor dicho el subproducto, que la ciudad segrega y exporta al medio rural, no es un producto tipificado sino un producto voluble de bajísima calidad donde frente al anonimato de la norma lo que prevalece es el vanidoso personalismo del quiero y no puedo.

En suma, lo que primero queda gravemente amenazado de la arquitectura típica regional es precisamente su tipismo, su tipología y en esto tienen una parte muy importante los factores psicológicos, la triste vanidad de personas infradesarrolladas culturalmente. Luego seguiremos tratando del infradesarrollo cultural.

La segunda amenaza que sufre la arquitectura típica regional radica en el atentado a su regionalismo y por ende a su casticismo, a lo que pudiéramos llamar sus caracteres raciales. Es evidente que este fenómeno es de alcance universal y desgraciadamente parece irreversible. Nuestra civilización tecnológico-industrial tiende a la uniformidad y a la desaparición de las notas diferenciales que definen a los pueblos. Esto conduce, inevitablemente, a un empobrecimiento del panorama cultural de la humanidad. Por esto la defensa de los caracteres 
diferenciales de las diversas comunidades humanas es una tarea que compete a nuestra época y que no hubiera tenido sentido en siglos anteriores a la Revolución Industrial en los que estos caracteres estaban preservados por su propia vigencia. El vigor del mundo campesino; la proporción mayoritaria de una economía agraria, el menor centralismo y mas tenue burocracia, con la consiguiente escasez de controles estatales; la escasez de vías de comunicación y la dificultad de los desplazamientos; la modestia de los medios de difusión que favorecían el aislamiento de las regiones naturales; la falta de medios técnicos avanzados capaces de superar los materiales y procesos artesanales; las formas estamentales de la sociedad; la transmisión de las costumbres, ritos y creencias hacían innecesaria toda preservación artificial de una atmósfera y de una cultura regional extraordinariamente vigorosa.

Lo que decimos puede llevar a la conclusión, pesimista para unos y optimista para otros, de que lo que es inevitable, es inevitable y que tratar de contener o paliar el movimiento irreversible del mundo actual es pura quimera y empeño que por artificial está condenado al fracaso. Como decimos, algunos pueden no sentirse afectados por este proceso y estimar que sólo nostálgicos tradicionalistas, que sólo añoran el pasado y que han hecho suya la divisa de que «cualquier tiempo pasado fue mejor», se sienten preocupados por estos problemas.

Pero esto no deja de ser un planteamiento simplista. Es cierto que lo que no se sostiene por sí mismo exige para su preservación un tratamiento artificial, si se quiere un cierto fingimiento, fingir que sigue teniendo realidad lo que de hecho no la tiene. Pero es cierto también que nuestra época ha desarrollado una conciencia histórica, un sentido historicista al que no pueden renunciar las sociedades cultas y que posiblemente se ha desarrollado como compensación de las fuerzas destructoras desencadenadas por la galopante evolución de la vida moderna en todas sus manifestaciones. Es algo así como un anticuerpo para combatir un virus pernicioso. Tan evidente como pueda ser esta evolución lo es la existencia del anticuerpo defensivo y por eso decimos que el problema no puede encararse de una manera simplista atendiendo sólo a uno de sus sectores. Si unas tensiones (las reformistas) conducen a la sociedad en $\mathrm{n}$ cierto sentido, otras (las conservadores) la solicitan según un diferente ángulo. Aquí podemos apelar a la imagen del cuadrilátero de fuerzas y decir que lo necesario es controlar la resultante más conveniente, como si se tratara de un problema de estática gráfica.

El sentido historicista es tan irrenunciable como pueden serlo los factores evolucionistas. Si la humanidad abandonara este freno se produciría una regresión no sólo cultural, sino humana en los*términos 
más generales, que podría conducirnos a una verdadera catástrofe, equivalente a un crimen de lesa humanidad. Podría la humanidad avanzar por la vía del desarrollo tecnológico, pero caeríamos en la barbarie mecanicista que obturaría las fuentes de la vida espiritual, cada vez más amenazadas pero cada vez también más necesarias para el equilibrio psíquico de un hombre sometido a los excesos del maquinismo.

Por lo tanto, la defensa del patrimonio cultural de la humanidad es algo inexcusable y si para salvarlo hay a veces que apelar a procedimientos un tanto artificiales, es el tributo que hay que pagar para lograr un equilibrio que hoy por hoy no acertamos a conseguir de una manera más suave y espontánea.

Los caracteres diferenciales de este patrimonio cultural, es decir, los caracteres castizos, los más amenazados, son los que exigen un tratamiento más delicado. Entre éstos puede contarse la preservación del legado lingüístico, lenguas muertas, lenguas en desuso, formas dialectales, etc. Es evidente que el proceso universalizador y nivelador del mundo moderno, unido al sentido pragmático, va reduciendo los idiomas a un instrumento funcional con dominio de los más extendidos, más flexibles y más próximos al lenguaje técnico. Entonces el pez grande se come al chico y unos idiomas mamouth lo acaparan todo. Si no existiera el antídoto de la conciencia historicista, el legado lingüístico se empobrecería de una manera alarmante. Por eso filólogos, lingüistas, folkloristas, se esfuerzan en mantener lenguajes que apenas tienen cabida en la vida práctica pero que son un testimonio cultural de primer orden. ¿Quién se atrevería, por ejemplo, a sostener que no vale la pena mantener el idioma vascuence? Pues lo mismo sucede con la arquitectura típica regional, que es necesario conservar por las mismas razones. Entre otras cosas porque la arquitectura es fundamentalmente un lenguaje cultural con independencia de su valor utilitario. La arquitectura regional es una de las manifestaciones del lenguaje de la región y, desde luego, de las más valiosa, pero por todo lo que decimos de las más amenazadas.

Contra esta amenaza no existe más antídoto que el sentimiento historicista, la conciencia del valor del patrimonio histórico. Ahora bien, ¿quiénes tienen esta conciencia? Justo es decir que en los países infradesarrollados culturalmente, sólo muy escasas minorías. La gran mayoría, activa o silenciosa, carece de ella. Ni las autoridades que tienen en su mano el poder de decisión, ni las clases que detentan el económico, ni la masa neutra que se deja conducir por el ejemplo que encuentra más extendido poseen esta conciencia. Sólo muy escasas minorías que aumentan conforme aumenta el grado de desarrollo cul- 
tural del país, que a su vez es consecuencia de un proceso civilizador más exigente. La tabla de valores de los pueblos es muy distinta y se da el caso que determinados valores que habían perdido toda significación para los naturales de un país, tienen que ser descubiertos por otros pueblos culturalmente invasores. Por ejemplo, la labor civilizadora que se llevó a cabo en Marruecos hizo por la valoración, defensa y protección del legado cultural islámico lo que nunca hubieran hecho los naturales que, psicológicamente, sentían el complejo de imitar lo europeo despreciando lo propio.

Un caso curioso se presenta por ejemplo, en nuestra Costa del Sol, donde se da, paralelamente, un fenómeno de destrucción y de reconstrucción del ambiente. Por un lado la presión económica que lleva consigo el boom turístico produce una construcción en gran escala, hoteles, bloques de apartamentos, residencias, que desfiguran notablemente el ambiente y atentan sobre todo a su fisonomía, pero por otro lado pueblecitos andaluces de arquitectura típica son objeto de una nueva atención y valoración que no se debe a un movimiento defensivo de los naturales del país en lucha contra la invasión, sino a los propios invasores, que, prendados del hechizo de estos encantadores pueblos andaluces, los miman y los cuidan, valorando lo que los naturales no aprecian por faltarles un nivel cultural y una sensibilidad estética. Son, pues, las élites invasoras las que provocan este fenómeno.

En términos generales se puede decir que los naturales de una región o de una ciudad histórica suelen ser sus peores enemigos, salvo en los raros casos en que estos naturales alcancen un alto grado de ilustración. El refrán de fuera vendrá quien de casa te echará se puede completar con este otro: de fuera vendrá quien tu casa cuidará. En realidad el mecanismo es bastante simple: primero, el nativo no aprecia lo que tiene delante de sus ojos, porque lo ha visto desde siempre, porque le faltan elementos de contraste para valorarlo y sentir su específico carácter; en segundo lugar, no lo mira como un espectáculo sino que lo soporta y asocia su imagen a sus penalidades e incomodidades. Por lo tanto, la imagen le es más bien ingrata e intentan evadirse de ella. Podemos decir que mucha de la arquitectura que se hace en aldeas, pueblos o pequeñas ciudades tradicionales imitando la arquitectura urbana es en realidad una arquitectura de evasión en la que el lugareño aspira a crear un ideal que le libere de su terruño. Cuando este lugareño ha hecho fortuna o, como ahora se dice, ha tenido una promoción social, el caso es todavía más grave, porque en la casa que se hace en el pueblo o en el edificio de altura con que quiere aumentar sus ganancias y épater a sus convecinos 
siempre busca disonar del medio, para hacerse notar y para demostrar, con un signo de prestigio, su liberación del marco tradicional que significaba su anterior condición de sometido. Los humildes encumbrados que reniegan de sus orígenes o los ocultan cuidadosamente para instalarse mejor en su nueva condición, actuarán así en todo aquello que pueda ser manifestación propia. Su casa, los edificios que promueven, las reformas urbanas que puedan ejecutar, si son autoridades, llevarán este sello evasivo, síntoma de un peculiar estado psicológico. De todo ello hemos tenido abundantes pruebas en nuestra larga vida de arquitecto, de restaurador de conjuntos históricos y de observador de la vida local.

Contra estos factores psicológicos no hay más que una manera de luchar: uniendo a esa promoción social una promoción cultural, capaz de hacerles variar su propia tabla de valores, hasta que sean ellos mismos los que entiendan de una manera diferente los signos de prestigio. Mientras esto no suceda las sociedades locales serán siempre enemigas de la arquitectura típica regional que les recuerda su pasado y partidarias de una arquitectura de evasión.

A las personas pudientes de Cuenca, ponemos por caso, nunca se les hubiera ocurrido reconstruir viejas y evocadoras casonas del caso viejo de la ciudad, prefiriendo con mucho vivir en lujosos -o pretenciosamente lujosos - pisos del ensanche, en casas con portal de mármol y ascensor automático. Signo de prestigio para ellos mucho más evidente que el de mantener las viejas casonas. Sin embargo, ha venido una minoría del exterior, una élite, en este caso especialmente sensibilizada, que ha adquirido casas viejas llenas de carácter y las ha convertido en residencias y estudios de un gusto admirable. Me refiero al grupo de pintores que en Cuenca han creado una pequeña colonia de artistas en torno al Museo de Arte Abstracto. Y en este caso no puede decirse que se trata de personas retrógradas que no pertenecen a la vanguardia artística de nuestros días y han sido los audaces exploradores de nuevas tendencias plásticas. No es, por lo tanto, un caso de progresismo o de reaccionarismo, sino un problema de sensibilidad y de educación. Mientras esta sensibilidad y educación no se desarrollen, el legado de nuestra arquitectura castiza está en peligro.

La tercera amenaza que sufre la arquitectura típica regional reside en la dificultad de mantener su esencial folklorismo. Esta arquitectura, ya lo hemos dicho, dimana de la sabiduría popular, del saber del pueblo, es su obra legítima y naturalmente colectiva. Pero hoy la arquitectura ya no es obra del pueblo, lo es de unos facultativos de grado superior o de grado medio que han sido formados al margen de la sociedad 
campesina, en centros urbanos importantes. En la tensión que se produce entre las sociedades de un medio no urbanizado y otro urbanizado siempre vence, cada vez más, la sociedad urbana, hasta el punto que ya apenas existe lo que los anglosajones llaman folk-society, si no es reducido a ciertas tribus aisladas objeto de estudio para los antropólogos. Sin embargo, en la sociedad campesina del período prerrevolucionario-industrial se mantenían muchos aspectos de la folk-society, según Robert Redfield, es una sociedad primaria, aislada, es decir, cerrada en sí misma, inmovilista, organizada dentro de un sistema de costumbres (que los antropólogos llaman «cultura»), iletrada, o sea carente de saber libresco y cuyos conocimientos se transmiten por tradición oral y basada fundamentalmente en un orden moral, en ningún caso técnico, administrativo o económico.

Es indiscutible que una villa castellana anterior a la Revolución Industrial no era estrictamente una folk-society como puede serlo una tribu australiana o una comunidad de indios papago de Arizona; pero no obstante quedaban en ella, aunque más diluidos, muchos de los caracteres de la fold-society ideal que hemos apuntado antes. Muchos aspectos de la «cultura» de estas villas o pueblos castellanos tenían ese sentido tradicional, mantenido bajo un orden moral y transmitido por una tradición oral. Un aspecto de esta cultura no despreciable, antes bien muy destacado, fue el de la arquitectura, que como lenguaje expresivo de un pueblo es tan importante como el romancero, el baile y la música populares. Toda esa arquitectura propia, la que ahora llamamos arquitectura típica regional, se produce desde la misma entraña que otros aspectos del folklore encarna, como diría Manuel Bartolomé Cassio, «los últimos y más hondos elementos, aquellos datos primitivos del alma de la multitud, que por esto se llaman naturales».

Toda esta arquitectura típica regional no era producto de una cultura erudita y menos libresca; era, por el contrario, consecuencia de una actividad empírica basada en la razón natural, como ha dicho Torres Balbás: «El pueblo construye todo empíricamente trabajando directamente el material, sin corrección posible, sin plano, sin premeditación de concepto».

La razón natural hace que esta arquitectura quede profundamente unida al suelo, al clima y al paisaje como un verdadero precipitado geográfico. Leoncio Urabayen, que estudió la arquitectura popular navarra, la considera resultado de una transformación en la que el suelo proporciona la primera materia, el hombre la actividad transformadora, y la necesidad, el motor que pone en contacto ambos elementos. Suelo, costumbres y necesidad significaban la dependencia inmediata del me- 


\section{Riesgo y desgracia de las ciudades históricas}

dio, que era monarca absoluto antes de que la incidencia de la sociedad urbana, con su cultura abstracta y libresca, incidiera avasalladoramente en él desarticulándolo totalmente.

En una maravillosa villa monumental amurallada, cuyo nombre no hace ahora al caso, me ha tocado intervenir restaurando algunos de sus monumentos más notables y vigilando con no poco esfuerzo y diplomacia la preservación de su caserío típico, pues se trata de una localidad declarada conjunto histórico-artístico. En sus apretadas calles de piedra oscura patinada por los años, habían empezado a surgir aquí y allá, como gritos estridentes, fachaditas de ladrillo de un rojo agrio, voladizos de hormigón, revestimientos cerámicos, gresites, carpinterías cromadas y todo el elenco de signos demostrativos de una cultura urbana, claro está de la más baja calidad. Con ansias de modernización se derribaban viejas fachadas de piedra y se sustituían por esta deleznable pacotilla. Propietarios y constructores hacían gala al unísono de su capacidad para liberarse de la tiranía del medio e iban del brazo tan contentos. Psicológicamente ese afán de liberación ya hemos dicho la fuerza que adquiere entre las personas simples y un poco vanidosas. El apólogo de la lámpara de Aladino se viene repitiendo al correr de los siglos y todos conocemos las historias de los salvajes que trocaban fabulosas riquezas por algunas chucherías y espejuelos que les ofrecían avisados y voraces traficantes del mundo civilizado.

Como desgraciadamente suele pasar, en esto como en tantas cosas se toma el rábano por las hojas y en lugar de mejorar las condiciones reales de vida y de tomar de la civilización aquello que es efectivo y deseable, salubridad, instalaciones, confort, se toman los más triviales signos externos sin que por otro lado mejore lo que substancialmente debía mejorar.

Como decimos, esta mentalidad empezaba a hacer su mella en el noble continente de una villa ejemplar que había llegado hasta nosotros casi intacta. Empecé a predicar pacientemente tratando de provocar el orgullo de los vecinos por ser depositarios de unas bellezas artísticas que los de fuera venían a admirar y que eran en realidad obra suya, de sus progenitores, y de ellos mismos si las sabían conservar, mantener y acrecentar con el debido gusto.

Pero también he observado que en el lugareño o en el ciudadano de ciudades vetustas se suele dar un curioso desdoblamiento de la personalidad. Esto lo he visto muy claramente en Toledo y sin duda se producirá en Segovia y en tantos otros lugares similares cuya psicología conozco menos. Este desdoblamiento consiste en que conviven en la misma persona, sin que ella se dé cuenta de su contradicción, 
el orgullo de las glorias históricas y artísticas y el disgusto, yo diría casi náusea a veces, que estos mismos testimonios le producen. Un toledano puede a la vez sentir el orgullo de su catedral, de sus misteriosas callejuelas y del tesoro que le dejaron los pinceles del Greco sin que por ello se sienta vinculado en su raíz última a lo mismo de que pregona ufano y no ponga pasión en defenderlo cuando de veras se atenta contra ello, antes bien se sienta liberado en su condición de hombre moderno.

La psicología actual del habitante de las llamadas ciudades históricas valdría la pena estudiarse. La mayoría sienten un complejo de prisioneros, de estar algo así como encerrados en la jaula de la Historia; de ser un poco objeto de museo. Lo comprendemos, pero en el fondo esta especie de esquizofrenia, de ruptura mental, no es más que un estado de enfermedad que es preciso superar y que consideramos fácil de superar en una sociedad evolucionada y culta. Lo que sucede es que esa aparente incompatibilidad cuando se logra una síntesis orgánica entre el ayer y el hoy, cosa que no pertenece al plano de la utopía ya que se ha logrado en muchas ocasiones, con evidente fortuna. No creemos que ningún ciudadano de Amsterdam sienta el complejo de prisionero de la Historia, ni de fósil museable porque su ciudad sea una de las más bellas del mundo y se conserve con la delicadeza que se conserva. No ha necesitado romper el pasado para haber avanzado como el que más en el campo de la arquitectura y del urbanismo dentro, además, de su misma y extraordinaria unidad.

Pero en fin, de digresión en digresión nos alejamos de la villa amurallada donde había que imponer, por la persuasión, más que por las leyes, criterios que defendieran la arquitectura típica. Tuve la fortuna de encontrar cuando menos lo pensaba un hombre que desde entonces fue mi brazo derecho. Era un constructor modesto y me pidió licencia para llevar a cabo algunas reformas y obras pequeñas que tuvieron el placet de Bellas Artes. De una manera sencilla le fui exponiendo mis ideas y él, con un talento natural nada vulgar, lo fue asimilando todo con la mayor naturalidad, porque no había nada más que abrir los ojos para darse cuenta que lo que se le pedía no estaba ni en mis deseos ni en mis opiniones, sino en la realidad que tenía ante sus ojos y en lo que allí se venía haciendo desde siempre. Todo iba, pues, sobre ruedas, pues las modestas construcciones o reformas que allí se hacían, o eran obra suya, o a mi requerimiento las vigilaba y orientaba. Cuando algunas personas querían emprender alguna construcción sin saber cómo hacerlo, yo le dirigía hacia esta persona diciéndole: "Él le aconsejará, pues conoce perfectamente lo que conviene hacer y en caso de duda está en relación conmigo». 


\section{Riesgo y desgracia de las ciudades históricas}

Pero pronto intervino una Delegación del Colegio de Arquitectos y presentó ante el Municipio y ante mí mismo razonada queja porque a este constructor no le asistía ningún título profesional para llevar a cabo aquellos trabajos. Les dije que tenían razón pero que dado lo insignificante de la mayoría de las obras y su probada práctica podría transigirse. De todas maneras las cosas se complicaron y a partir de entonces los planos firmados por arquitectos me dieron no pocos quebraderos de cabeza. Eran planos de estudio profesional y venían de la ciudad. No se adaptaban ni al carácter ni al espíritu de la añosa villa, todos tenían pretensiones y formalismos que no hacían al caso.

Aquí tenemos un caso claro de tensión entre dos mundos, el local, el de la sabiduría y buen sentido populares, y el urbano, técnico y profesional, que la sociedad actual impone.

La arquitectura típica regional no puede, por lo tanto, mantener su esencial folklorismo, se ve amenazada por la sociedad urbana y sus estructuras administrativas y tecnológicas. Por lo tanto, vano sueño pretender que unos albañiles, unos maestros de obra modestos y sin pretensiones sigan ejerciendo el papel que jugaron en otros tiempos. La experiencia que acabo de relatar es lo bastante contundente para desengañarnos. Hay que buscar la solución por otros caminos. Ya que no podemos resucitar el alarife de antaño, no tenemos más remedio que dar un rodeo y desandar el camino, es decir, volver al alarife desde el arquitecto, en otras palabras, pasando por el arquitecto. No es cosa fácil porque la ingenuidad, naturalidad y despersonalización del maestro de otros tiempos contravienen a la formación o deformación profesional del técnico. La sabiduría popular de aquél sólo obedecía a las condiciones del suelo; a la conservación de unas normas tradicionales(no aprendidas en los libros sino por transmisión directa y por impregnación reiterada dentro de un medio recluso) y al servicio de una necesidad no alterada por el capricho pasajero de las modas. Exactamente todo lo contrario que mueve al técnico de nuestra sociedad urbanizada. Un técnico que no pisa el suelo, paisaje, clima, materiales, geografía en suma; que trabaja en el utópico (es decir, sin lugar concreto) tablero de dibujo de un estudio profesional; que todo lo aprende a través de la letra impresa y del peligroso vehículo de las revistas de arquitectura que son como el escaparate de una ferie de vanidades donde hay que destacar a toda costa; un técnico que diciéndose servidor de la función (nuestro tan cacareado funcionalismo) sacrifica la función y la necesidad casi siempre al capricho, al viento que corre por las cimas de la creación arquitectónica donde sopla el más desenfrenado egocentrismo. 
Amenazada la arquitectura típica regional en su tipismo, es decir, en su tipología y norma; en su casticismo o regionalismo, destruidos por la confusión de las lenguas y el internacionalismo, y en su folklorismo, al sustituirse la sabiduría popular colectiva por el profesionalismo individualista, hemos visto a través de nuestro discurso la enorme cantidad de factores psicológicos que intervienen en el desencadenamiento de unos hechos, al parecer fatales e irreversibles.

Pensando así, al final, el pesimismo nos embarga, pesimismo, ante las múltiples amenazas que acechan a esta arquitectura, que tanto nos seduce con su entrañable lenguaje, que es íntima confesión de nuestra raza y espejo de nuestra historia o mejor de nuestra intrahistoria, como diría Unamuno, y nuestro balance último sería francamente negativo.

Pero no queremos reducirnos a entonar un fúnebre réquiem $\mathrm{y}$, como el piloto a punto de caer en picado, queremos con un golpe de timón remontar el vuelo con alegre esperanza. Mientras analizábamos la situación critica por la que pasa esta arquitectura mucho más difícil de conservar que los grandes monumentos, íbamos a la vez apuntando soluciones al mal -al menos las que a nosotros nos parecían - de tal manera que no nos conformábamos con el pesimismo del diagnóstico sin exponer al lado la solución del remedio. En último término estos remedios se reducen a uno, lo mismo que los Mandamientos del Decálogo se reducen a dos; a amar a Dios sobre todas las cosas y al prójimo como a ti mismo. En nuestro caso es un problema de cultura, de ilustración; en suma, de educación de las masas, educación de las clases dirigentes, educación de los técnicos.

Todo esto es muy fácil de decir -objetarán algunos-porque las extremas generalizaciones a fuerza de amplitud se desvanecen y no sirven para alumbrar caminos. Tampoco quiero que se me tilde de vago y generalizador y para salvar este escollo quiero proponerles a ustedes, siempre en la línea de mi discurso y a un riesgo de repetirme, algunos de estos remedios un poco más concretos.

En primer lugar siempre que queramos intervenir dentro de un medio arquitectónico impregnado de carácter y donde la personalidad típica sea muy acusada tenemos que volver a la norma, al tipo y, no nos asustemos, al «estándar», si es preciso. Tenemos que construir con unos módulos de extremada sencillez y harán menos daño en un medio de este tipo unas viviendas prefabricadas de volúmenes y superficies simplicísimas que las caprichosas y volubles con las que queremos dejar un falso sello de contemporaneidad.

Yo ilustraría lo que digo poniendo frente a frente la estética de la casa de peón caminero frente a la estética del chalé. La estética casa- 


\section{Riesgo y desgracia de las ciudades históricas}

de-peón-caminero es una lección de buen sentido y humildad. (No sé si por eso las han hecho desaparecer todas, como si nos molestaran por su misma pureza planteándonos un caso de conciencia). La estética del chalé es en cambio algo abominable, la peor expresión de una vanidad burguesa de quiero y no puedo. Hoy prevalece la estética del chalé, cuanto más torturado mejor, cuanto más chillón y estentóreo mejor. También se trata en este caso de unos factores psicológicos de una sociedad en ascenso que quiere imitar al standing de las clases altas. Si hoy a un miembro de esta sociedad en ascenso se le proyecta para casa fin de semana, una casa de peón ingeniará para acumular tejaditos que no coinciden, que van cada cual para su lado sin orden de concierto y toda clase de extravagancias que satisfagan la petulante vanidad de su cliente.

Si nos fijamos en la composición volumétrica de un pueblo de Castilla veremos que se compone de una suma de elementos muy simples en sí. Casas unidas por las medianería con tejado a dos aguas, unas vertiendo a la calle, otras al corral o patio trasero, cuando no a una calle posterior. Pueden ser una serie de casas de peón caminero (en general más profundas y estrechas) pegadas unas a otras. Bastan leves variaciones en las alturas de los aleros y en el diseño de los mismos para que se produzca una graciosa variedad en la uniformidad. Ahora bien, soldemos una serie de chalés, que es más o menos lo que parece que nos gusta y desembocaremos en la catástrofe estética, además de incurrir en muchos problemas de carácter práctico que las soluciones lógicas y naturales resuelven. Todo esto sucede porque hemos perdido el sentido de la norma, la sencillez tipológica.

En segundo lugar tenemos que salvar el regionalismo, sin que nos asuste la palabra.

Un gran arquitecto alemán, hoy un poco olvidado porque no formó parte de la Bauhaus y porque éstos acapararon el primer plano de la posguerra por haber sido perseguidos por el nacismo, Heinrich Tessenow, solía decir que todo estilo emana del pueblo, que el internacionalismo no puede producir ninguna cultura verdadera. Y que conste que Tessenow no tenía nada de arqueoligizante ni menos de pastichista, sino que pertenecía a la línea más exigente y depurada del movimiento moderno. Pero una de sus máximas, acaso no suene hoy muy amablemente a los oídos de las nuevas generaciones de arquitectos. En arquitectura para Tessenow, lo esencial era hacer lo menos posible.

Hombres, ideas como las de este arquitecto son las que nos hacen falta para recuperar el estado de pureza con el que hay que acercarse a la arquitectura regional. Al linaje de Tessenow pertenecía nuestro 
Carlos Arniches Moltó, un arquitecto delicado y sensible que comprendió el espíritu popular sin adularlo, viendo lo castizo en su esencia y en su pureza. Hoy, José Luis Fernández del Amo ha logrado también acercarse a este ideal. Casticismo sin ramplonería es lo que pedimos, sin entrar ahora a juzgar si el internacionalismo es o no malsano para la creación artística en general. Nosotros ahora nos ocupamos de una cosa distinta y que no es otra sino de la manera de preservar el ambiente típico regional y de intervenir en él sin violentarlo y sin adularlo con copias ramplonas.

Hoy en día intervenimos en este ambiente violentándolo de dos maneras a cual más perjudicial: trasladando a su escenario los productos de un internacionalismo sin raíces, originado en el medio descastado de la gran ciudad o adulándolo chabacanamente y realizando una arquitectura costumbrista del peor estilo. Ni lo uno, ni lo otro. Lo que pedimos es un estado de pureza, y como decía Tessenow hacer lo menos posible, que en el fondo es lo que hicieron los maestros anónimos que edificaron nuestros inconfundibles pueblos y villas del pasado. Pedimos también que no caigamos en esta babel arquitectónica, en esta confusión de lenguas que constituye el galimatías lingüístico en el que nos movemos. Ni esperantismo uniforme y vacuo que anule todo carácter, ni babelismo confusionario que mezcle todas las cosas. No olvidemos que la arquitectura es un lenguaje y que lo mismo que debemos defender con cautela la pureza del castellano, del catalán, del gallego o del eusquera para no convertirlos en un galimatías de extranjerismos o neologismos, tampoco debemos manchar el lenguaje arquitectónico regional con términos espúreos. Es el verdadero problema al que nos referimos cuando hablamos de casticismo. Lo primero que debe hacer el arquitecto que tiene que intervenir en un medio regional es aprender el idioma de la región. Para aprender un idioma lo que tenemos que hacer es leer y leer buena prosa, para aprender el idioma arquitectónico lo que tenemos que hacer es mirar y mirar sabiendo captar las esencias, los invariantes, las constantes que repetidas dan como precipitado el carácter regional.

En tercer lugar volvamos de nuevo al folklorismo de la arquitectura regional para ver los problemas que esto nos plantea y sus posibles remedios. Decimos que una arquitectura es folklórica en el buen sentido de la palabra cuando es consecuencia del sabor del pueblo. En tiempos lejanos casi toda la arquitectura era consecuencia del saber del pueblo. En muy pocos casos la arquitectura era obra de eruditos, de humanistas, de gentes cultivadas o letradas. Esto vino con el Renacimiento para luego descender otra vez hacia la artesanía y por último con la Ilus- 
tración y las Academias empezar de nuevo a salir de las manos del pueblo. Así como en los siglos pasados el inmenso porcentaje de la población humana lo constituía la población agraria y el ínfimo la urbana, así casi toda la arquitectura era de raíz popular y en muy pequeña escala cortesana. Hoy en día va desapareciendo la población agraria y con ella la vieja cultura campesina anegada por la invasión ciudadana que no sólo es mayoritaria sino que no encuentra resistencia en el agro, que ha capitulado de antemano ante los modelos urbanos.

Ya no podemos pretender que la arquitectura típica regional sea una planta cultivada por el pueblo artesano, ya ni nuestra legislación lo permite. Tenemos que recurrir a procesos antinaturales. La arquitectura del ambiente típico ya no puede ser hija de sus padres, que nos hemos propuesto esterilizar y debemos mantener la especie por inseminación artificial. Tenemos que repetir el acto biológico y natural en el proceso de laboratorio y esto que hasta cierto punto parece monstruoso puede, sin embargo, dentro de determinados límites, ser aceptable. Es decir, podemos aprender la lección del pueblo, cuando el pueblo era un agente creador activo - que hoy no lo esy aprendida esta lección lograr para nuestra obra algunas de sus indiscutibles virtudes.

Uno de los rasgos de aquella arquitectura del pueblo y para el pueblo residía en el recto uso de los materiales y en el enorme valor caracterológico que estos materiales la otorgaban. Lo mismo que no era indiferente a su geografía, a su climatología, a sus necesidades tradicionales, no era nunca indiferente a sus materiales y en gran medida eran éstos los que la caracterizaban, porque no eran escogidos al azar sino determinados por la realidad y la fuerza del medio.

Por ejemplo. Tres son los materiales empleados para la construcción de las viviendas castellanas: el barro sin cocer en forma de tapial o tapiería o en forma de adobes, el ladrillo y la mampostería. Con estos materiales se conjuga más bien como elemento auxiliar la madera, que en ocasiones esconde tímida su actividad y en otras, más ufana, impone su presencia en balconadas, galerías o aleros, nunca tan prominentes y labrados como los norteños. El tapial y el adobe se emplean sobre todo en la llanura desnuda y arcillosa de la Tierra de Campos, en los páramos leoneses, en las tierras llanas producidas por la erosión de los cerros del mioceno. En la región arenosa del sur de Castilla, tierras sueltas del pinar y del vino, se usa el ladrillo combinado a veces con un hormigón formado por pequeñas piedras de río. Gran parte de las provincias de Segovia y Ávila, llegando por el norte a Sepúlveda, Cuéllar, Tordesillas y Nava del Rey, entran dentro de esta región. 
La mampostería se usa sobre todo en los bordes de mesetas y páramos, en los que las aguas han dejado al descubierto afloramientos calizos y junto a las sierras que limitan la gran meseta castellana. La madera, como hemos dicho, es ingrediente auxiliar en casi toda la arquitectura típica castellana. Los pisos superiores solían hacerse de entramados más ligeros y resistentes, mientras que los bajos eran de mampostería o tapial en fuertes espesores. Los entramados eran pobres y por eso generalmente se ocultaban (en Segovia con la elegante solución del esgrafiado), saliendo sólo a la superficie las cabezas de las vigas de los pisos, de mejor madera, sobre todo cuando éstos volaban unos sobre otros. Muchas veces estas cabezas se recortaban con perfiles mudéjares, índice de la influencia hispano-morisca.

La madera en algunos casos abandonaba su humilde papel de sirvienta y salía a la luz como protagonista. Es el caso de las casas con grandes balcones volados y solanas de la serranía central, el de las casa de Riaza o Ayllón, de las de tierras de pinares de Soria y Burgos, en torno a la sierra de Urbión, de las de la vera y el valle del Tiétar, casas que llegan hasta Portugal por las estribaciones de las sierras de Francia y Gata.

Con indudable humildad y restricción, tanto en los materiales como en las formas, la arquitectura típica castellana está llena de matices e inflexiones que no podemos ni mucho menos detallar aquí.

Lo que queremos significar es que ese recto uso de los materiales del que nos dio tan excelentes ejemplos la sabiduría popular no tiene por qué perderse del todo. Los pesimistas nos dirán que ya no se puede luchar con los materiales modernos, con los productos de la industria que lo avasallan todo, que intentarlo es como un vano empeño de volver a la Edad Media y trocar nuestros trajes de naylon por las pesadas armaduras. Pero salvo que en la Edad Media casi nadie, más que algunos magnates, llevaban armadura, la distancia entre un tejido de estameña bien arcaico y uno de los nuestros no es tan grande como parece. Pues lo mismo pasa con los materiales. No nos rasguemos las vestiduras, hoy seguimos construyendo con ladrillo, con mampostería y con hormigones como en tiempos de los romanos y donde se ha producido realmente un mayor cambio es en las estructuras, con el hierro y el hormigón armado y en los elementos que afectan a los mecanismo de la construcción más que la construcción misma. Pero ni la arquitectura del medio rural ni la de la pequeña ciudad requieren alardes estructurales ni mecanismos complicados. Por eso los materiales tradicionales siguen siendo válidos y el contravenirlos es muchas veces más afán de novedad que otra cosa. En determinados medios es más 
fácil, hacedero y económico construir more tradicional que imponer por capricho los materiales que exige un tipo de construcción de alto nivel técnico. Económicamente el porvenir puede conducirnos a la prefabricación, pero ésta sólo es viable en gran escala y aunque fuera penetrando en el medio rural o semiurbanizado, como ya hemos dicho, su impacto no nos asustaría. La sencillez de los modelos que impone la prefabricación, antes bien, podrían salvar a nuestra arquitectura de rango modesto de la anarquía que la amenaza.

Por lo tanto, los tan traídos y llevados materiales modernos (hago exclusión de un agente especialmente nocivo y tentador, la cubierta de fibrocemento, la uralita) no son una amenaza en sí, la amenaza reside en el mal gusto y en la inconveniencia de su empleo que muchas veces parte de unos motivos que nada tienen que ver con la lógica y con la economía, y sí en cambio, aunque parezca extraño, con la psicología de las sociedades en un momento de transformaciones tan grandes como el que estamos presenciando.

El pueblo, que antes era depositario de un gusto innato natural y sencillo, ahora, al perder sus tradiciones y secular idiosincrasia, se ha convertido en un agente destructor de lo que él mismo, pacientemente y casi sin saberlo edificó. Es que no es el pueblo que era y en vez de continuar repudia a sus antepasados en los que no ve más que la imagen de un pasado de esclavitud. Por eso son las minorías cultas e ilustradas las que deben recoger amorosamente esa esencia abandonada y hacerla fructificar si aún es tiempo antes de que una ola de incomprensión y estulticia lo arrase todo. Así sea.

\section{COLOFON}

En estas desordenadas notas he tratado de discurrir sobre los problemas que atañen a las ciudades en general y a las llamadas históricas en particular.

Hemos querido destacar el valor eminente que representan las ciudades en el campo de la historia y como son un verdadero archivo de la misma.

Pero lo fundamental ha sido discurrir sobre los muchos factores que las amenazan en su caracter y su belleza que en algunos casos son extraordinarios. Somos conscientes de que las ciudades son seres vivos y que se transforman constantemente. De lo contrario serían fósiles arqueológicos. Ciudades muertas. 
Pero el hecho de ser organismos vivos, no quiere decir que tengan que crecer negándose así mismos, sino, por el contrario, afirmándose en su propia personalidad y belleza. Siempre tengo in mente una ciudad europea, como Amsterdan, una Venecia nórdica en sus canales, que siempre ha crecido con orden, elegancia y modernidad sin negarse a sí misma.

Sabemos que esto no es fácil y que requiere un alto grado de cultura, una población formada y educada desde su cuna y unas autoridades rectoras verdaderamente ilustradas.

Pero esto no se da en todas las latitudes ni es fruto de todos los árboles. Y ya que hablamos de árboles tomemos ejemplo de ellos, de como se desarrollan y crecen. El árbol, débil retoño en su nacimiento va creciendo y desarrollándose, engorda y fortifica su tronco, amplia su ramaje y desarrolla su copa, y tanto gana en grandeza como en belleza sin dejar nunca de ser lo que es. Un buen ejemplo metafórico para ilustrar el crecimiento de nuestras ciudades. 